\title{
A simple offspring-to-mother size ratio predicts post-reproductive lifespan
}

\author{
George Maliha and Coleen T. Murphy*
}

Lewis-Sigler Institute for Integrative Genomics and Dept. of Molecular Biology, Princeton University, Princeton, NJ 08544, USA

*Correspondence to: ctmurphy@princeton.edu

\begin{abstract}
Why do many animals live well beyond their reproductive period? This seems counter to the theory that the fraction of life spent reproducing should be maximized in order to maximize the number of offspring produced in each generation. To resolve this paradox, hypotheses have been developed that evoke parental or grandparental care as reasons for post-reproductive life (e.g., the Mother and Grandmother Hypotheses). However, these hypotheses fail to explain the presence of post-reproductive life in organisms that do not care for their young, such as Caenorhabditis elegans. Here we show that a candidate proxy of the stress of childbirth explains a large portion of the variance in post-reproductive lifespans across many species. A remarkably simple metric, the "offspring ratio" (ratio of the size or weight of offspring to that of the mother) explained $77 \%$ of the variance of the postreproductive lifespan in a sample drawn from widely dispersed taxa. Our results suggest that the stress of childbirth is an important and conserved determinant of post-reproductive lifespan. Thus, long post-reproductive lifespan may simply be a byproduct of the somatic health required for reproduction of large progeny, regardless of parental care.
\end{abstract}

Keywords: post-reproductive lifespan

\section{Introduction}

Although post-reproductive life is often thought of as a result of modern medicine's extensions of lifespan, even before these developments, human females were documented to go through menopause and spend the remainder of their lives without the ability to reproduce ("post-reproductive life") $[1,2]$. Women who were able to reproduce late in life (without modern reproductive assistance) also lived longer, suggesting a positive correlation between lifespan and reproductive span [3]. Previous work has hypothesized that while connected, reproductive and total lifespan could be under differential control (perhaps even trading off against one another) [4,5], but the reasons for this differential control have not been elucidated [4,5]. In addition to maternal aging effects on progeny quality, the onset of menopause has serious biological implications due to its effects on normal regulatory processes. For example, rates of cancer, cardiovascular disease, and other degenerative processes drastically increase post-menopause [6-8]. Therefore, elucidating the mechanisms that regulate onset of post-reproductive life and subsequent effects on aging has become more critical.

Several theories have been proposed to explain the existence of post-reproductive life through direct or indirect parental care. For instance, the "Mother Hypothesis" theorizes that females stop reproducing in order to concentrate their efforts and resources in raising already-birthed offspring $[9,10]$. Moreover, the presence of menopause and post-reproductive life can also protect existing offspring by discouraging males from mating with older mothers [11]. The "Grandmother Hypothesis" posits that post-reproductive females assist in the reproductive success of their daughters, through care of grandprogeny [9,12-14]. Mother and Grandmother Hypotheses concentrate upon direct benefits to children and grandchildren.

However, we and others have shown that $C$. elegans, like women, have a proportionally long post-reproductive life span (PRLS), despite the fact that they do not care for their 
young [15-19]. In addition, the existence of PRLS has been suggested in studies of brine shrimp (genus Artermia), Drosophila, Mabuya buettneri (the African Skink, a reptile), and other organisms [20-26]. Mother and Grandmother theories cannot account for the long post-reproductive lives of $C$. elegans and other organisms with non-human social structures. The limiting factor of $C$. elegans reproductive span is oocyte quality decline with age, as it is in mammals [16]. Moreover, oocyte quality is governed by similar gene sets in mammals and worms [16], suggesting that factors that regulate reproductive aging may be conserved evolutionarily. Therefore, we wondered whether there is a also conserved determinant of post-reproductive life span (PRLS) across species.

Here we show that such a factor does exist: the ratio of offspring size to mother size correlates well with length of post-reproductive life span across many species. We hypothesize that the offspring ratio may indicate the level of somatic integrity necessary to successfully reproduce, and our tests of this model in C. elegans suggest that altering these ratios can have deleterious effects on the mother's survival during reproduction.

\section{Methods}

Statistical Analyses: Linear regressions were conducted using native $\mathrm{R}$ functionality and the tools available from the "mlbench" package [27,28]. Graphical labels were constructed using the "calibrate" package [29].

Calculations: Several values were computed from the data: Post-Reproductive Lifespan ("PRLS"), Offspring to Maternal Size Ratio ("Offspring Ratio"), Reproductive Window (the proportion of life in which the species can reproduce), Maturity Proportion (the proportion of life spent maturing to reproductive age), Gestational Proportion (the proportion of life spent in gestation in a single reproductive cycle), and Weaning Proportion (the proportion of life spent weaning offspring from one reproductive cycle; only applicable to mammals).

PRLS was computed as the ratio of life after last documented reproduction to maximum documented life expectancy minus maturity time (the final factor facilitates comparisons outside of mammals) [30]. Offspring ratio was computed by taking the ratio of the offspring to maternal size or weight (depending on the data available). When weights were unavailable, the cube of the length of offspring at birth and mother was used. Litter size-adjusted ratio was computed by multiplying the average size of a litter by the offspring ratio. Reproductive Window was computed as the proportion of maximum lifespan between the age of maturity and reproductive senescence. Maturity Proportion was computed solely for mammals and birds as the ratio of maturation age (for females) to maximum lifespan (the data for nonmammals was not reliable enough). Gestational Proportion was computed similarly as the ratio of gestational time to maximum age.

The equations used to compute the values, then, were as follows:

(1)

$$
P R L S=\frac{\text { maximum lifespan }- \text { age at last birth }}{\text { maximum lifespan }- \text { age of female reproductive maturity }}
$$

(2) $\dagger$

$$
\text { Offspring Ratio }=\frac{\text { offspring weight at birth }}{\text { adult weight }} \text { OR } \frac{\text { offspring length }}{\text { adult length }^{3}}
$$

(3) Litter Size Adjusted Offspring Ratio $=($ Offspring Ratio $) *($ Average Litter Size $)$

(4) $\ddagger$ Reproductive Window $=1-\frac{\text { Age at Last Birth }- \text { Age of Reproductive Maturity }}{\text { Maximum Age }}$

(5) $\ddagger_{\text {Maturity Proportion }}=\frac{\text { Age of Reproductive Maturity }}{\text { Maximum Age }}$

(6) $\ddagger_{\text {Gestational Proportion }}=\frac{\text { Gestational Time }}{\text { Maximum Age }}$

(7) $\ddagger_{\text {Weaning Proportion }}=\frac{\text { Weaning Age }}{\text { Maximum Age }}$

TOffspring Ratio was calculated using weights if possible, but if not, lengths were used. If offspring length could not be found, it was approximated using the length of the female gamete (in the case of sea urchins). While among mammals it has been found that length to the fourth power (not third) relates to body weight, the use of logarithmic regression parameters renders the exact exponent irrelevant. Moreover, as a wide range of animals (not just mammals) were studied, it appeared more appropriate to use the natural geometric relationship [31].

¥This is only computed for mammals and some birds. There was not enough non-mammalian information is available to compute a similar value.

Data: A dataset was constructed in order to probe various aspects of animal aging. Data for mammals and most birds (both in captivity and in natural habitats) were primarily obtained from anAge: The Animal Aging and Longevity Database and the references contained therein [32]. 
Reproductive Senescence data was supplemented using previous reviews of primate and mammalian aging [33-35]. The selection of non-mammalian models was guided by previous aging studies [19,36-39]. Data for the following species were also obtained independently: Strongylocentrotus franciscanus (Red Sea Urchin) [40-45], Strongylocentroltus purpuratus (Purple Sea Urchin) [4143,46,47], Oncorhynchus tshawytscha (Chinook Salmon) [4851], Oncorhynchus kisutch (Coho Salmon) [49,50,52], Oncorhynchus keta (Chum Salmon) [42,49,50,53], Drosophila Melanogaster [21-24], Mabuya buettneri (African Skink, a reptile) [25,26], Gallus gallus domesticus (Leghorn-breed chicken) [54-56], Galeorhinus galeus (School Shark) [57-60], and Alligator mississippiensis (American Alligator) [61-63]. Different measures of longevity (and their values in various species) were obtained from analyses of the ISIS database of Zoo collections [64].

The following assumptions were made (also made explicit in the data tables): In general, the maximum documented age was either obtained from records or computed by summing the longest possible life history for an animal. Age of maturity and reproductive senescence were found by computing averages of given data. Where given, it was favored to take data from the same paper or source in order to maintain consistency among measurements. However, the sources did not fundamentally disagree with one another-and the results were relatively robust to changes in values. For the three species of salmon and two species of sea urchins, a post-reproductive period of one day was assumed (although the assumption was robust to increasing the PRLS and supported by observations), and age to reproductive maturity was assumed to be negligible in the case of the sea urchins because of their relatively long lives [65]. For the shark and alligator, the age of reproductive senescence was assumed to be the average lifespan of the organism, consistent with previous theoretical and empirical work [66]. In addition, age at reproductive maturity was used from either or both genders when considering all mammals-and separated by gender when considering mammals (due to data limitations). Since not explicit, for sea urchins, litter size and birth size was estimated by the number and size of (female) gametes. Since urchins are external fertilizers, though, we assume that this release is the most stressful part of "birthing" and will suffice.

\section{Data sets:}

Datatable 1 (Mammals)

Datatable 2 (All Animals)

\section{Results}

To assess whether there is a conserved determinant of postreproductive life span (PRLS) across species, we gathered information about life history features on a variety of animal taxa (96 species) both within and outside Mammalia, including sea urchins, salmon, Drosophila melanogaster, and species of reptiles and birds (Supplemental Table 1; Supplemental Table 2), for which we could obtain information on reproductive senescence, e.g., life span, age at reproductive maturity, adult size, progeny size at birth, and average litter size (see Supplemental information for all available variables). We then compared these features to the post-reproductive life span ratio (Figure 1):

$P R L S=\frac{\text { maximum lifespan }- \text { age at last birth }}{\text { maximum lifespan }- \text { age of female reproductive maturity }}$

Within mammals, no one factor accounted for the majority of post-reproductive lifespan, perhaps indicating that several different parameters contribute to the determination of postreproductive lifespan (Supplemental Table 1). In addition, humans (data from the hunter-gatherer-like Hadza and !Kung) were not outliers compared to other mammals.

However, a surprisingly simple metric, the ratio of offspring size to mother size, or "Offspring ratio," correlated well with PRLS across the larger set of species. The measure was computed in two ways depending on data available:

Offspring Ratio $=\frac{\text { offspring weight at birth }}{\text { adult weight }}$ OR $\frac{\text { offspring length }}{\text { adult length }^{3}}$

The unadjusted offspring ratio could explain approximately $75 \%$ of the variance of post-reproductive lifespan $\left(R^{2}=0.771\right.$; $p=0.000174)$ (Figure 1B). That is, larger offspring with respect to the mother is associated with longer postreproductive period of the mother. (Note that while litter size has an inverse and highly correlated $\left(R^{2}=0.869\right)$ relationship with PRLS (Figure 1C), it is also correlated with and inversely related to offspring ratio $\left(R^{2}=0.781\right)$, and thus cannot be distinguished from offspring ratio (Figure 1D).

In order to attempt to separate the effects of phylogeny from taxonomic adaptations, methods outlined previously were utilized [67,68]. Species-level data among mammals were averaged to the family level, recapitulating similar results and suggesting the presence of adaptation. Graphing the residuals of separate offspring and adult weight regressions against PRLS separated the available placental mammal from the single marsupial data point. As for the non-mammals, in 
order to capture more data points, we measured offspring ratio through two methods (outlined in Methods). However, the non-mammals are selected from a wide variety of taxa, and even when some of the closely-related species are averaged (e.g., sea urchins and salmon), the results do not change, lessening the concern about these differences emerging from phylogeny (although methods to separate phylogeny and adaptation are unavailable in this case).

Our comparison of offspring ratio to PRLS also roughly groups organisms by reproductive strategy. Clustered in the low

A

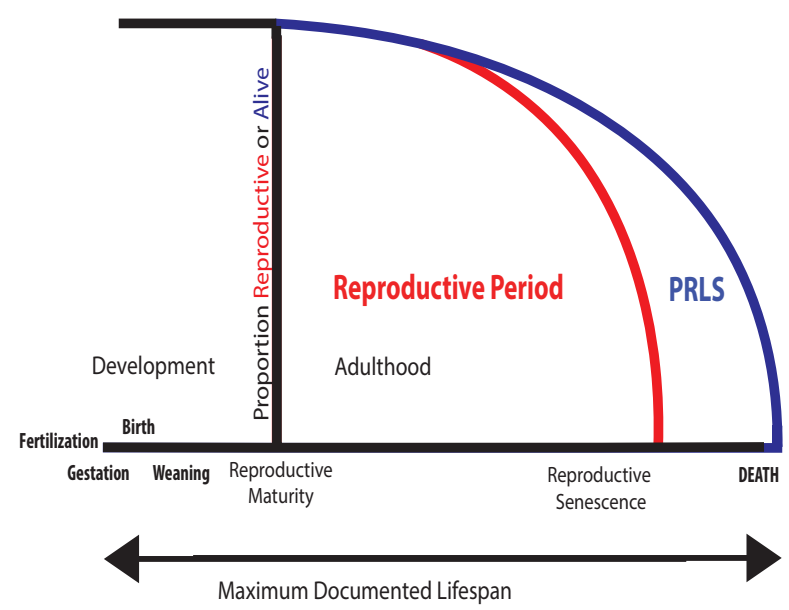

C

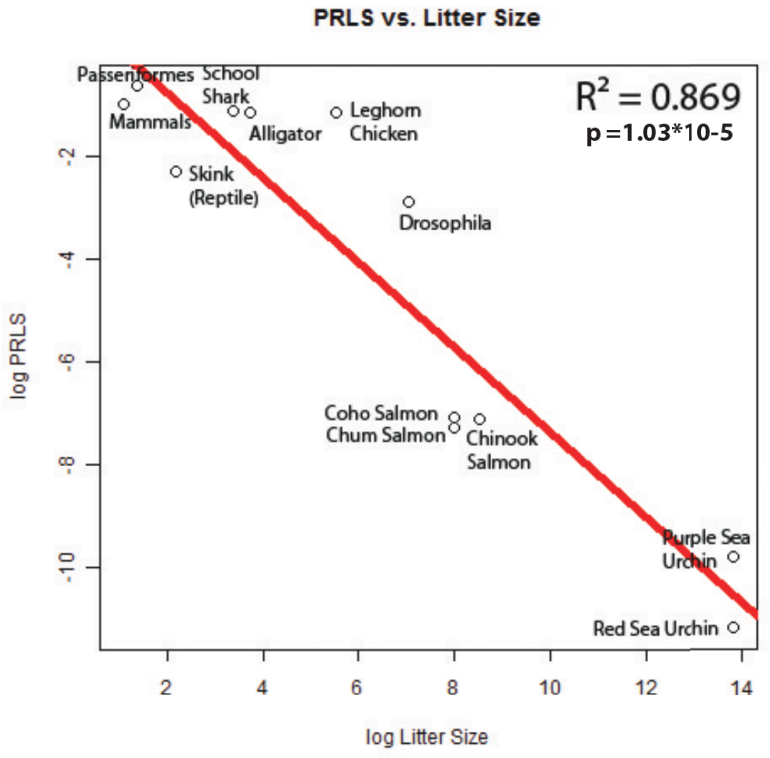

offspring ratio/low PRLS area of the graph are red sea urchins, purple sea urchins, and salmon species-all organisms that release unfertilized gametes into the environment (Figure 1B). The African Skink, Drosophila melanogaster, School Shark, and Alligator form another group, producing fertilized embryos that are released into the environment with no parental care (Figure 1B). Finally, birds and mammals-animals that care for their young-appear to form another cluster at the high offspring ratio/high PRLS region of the graph (Figure 1B).

B

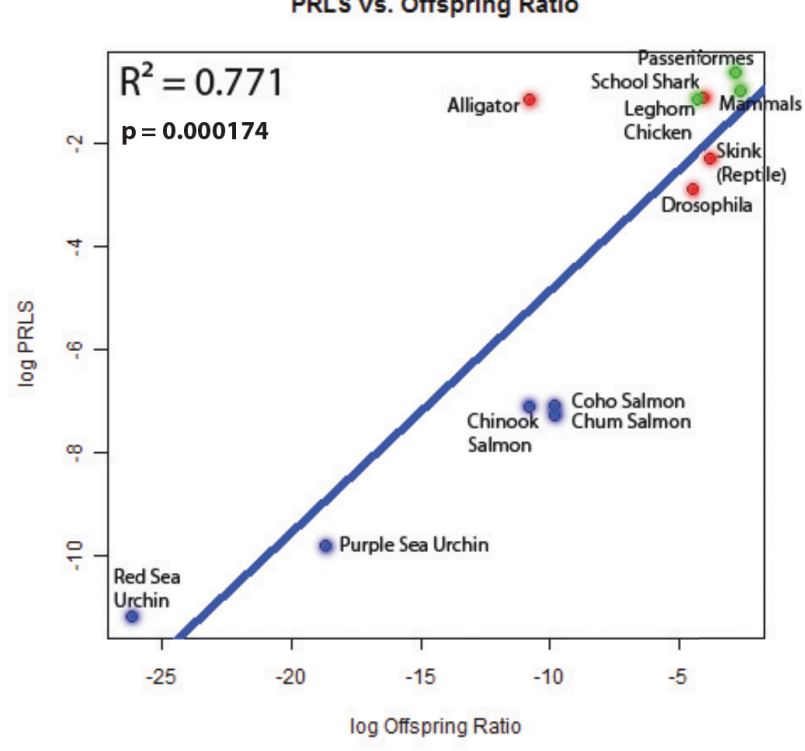

D

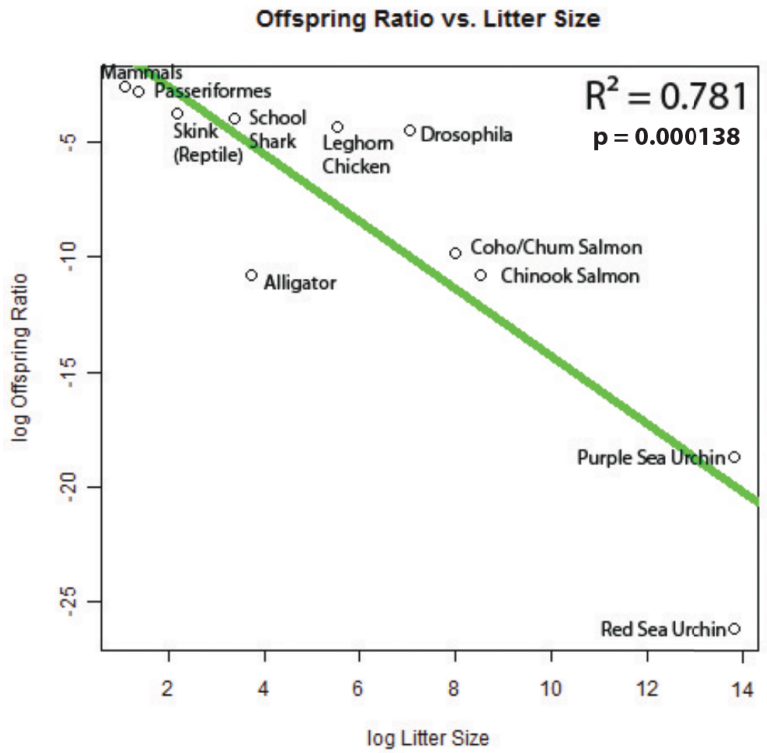

Figure 1. Post-reproductive life span correlates with offspring ratio 
When looking at the diversity of animals, it appears that those with the largest offspring ratios have the longest postreproductive lives, and vice versa. This result is counter to the notion that larger offspring deplete resources, resulting in a shorter post-reproductive life span. Indeed, our results suggest that there is not a direct "tradeoff" between reproductive and post-reproductive life [4]. Instead, we posit that the offspring ratio may be a proxy for stress of childbirth or progeny production. There is likely a point at which an organism cannot devote adequate energy or quality maintenance to reproduction but still has the necessary strength and physical integrity to live. Although in the absence of parental care, neither positive nor negative selection acts on PRLS, these correlations suggest a reason for the particular length of PRLS [5]. In essence, PRLS in many species is simply an unselected residual of life $[15,69,70]$, but the reason for this residual has not been tested previously. We suggest, based on the correlations found here, that more stressful or physically demanding forms of reproduction may require greater strength and integrity in the soma to successfully produce offspring, resulting in greater somatic integrity in the post-reproductive period and correspondingly longer PRLS. The physical manifestation of this threshold can be found when females are pushed to reproduce beyond a typical time: in humans, the most common cause of death of older mothers before the introduction of modern medical interventions was hemorrhaging during childbirth [71]. In the most extreme example in the other direction, sea urchins release millions of one-cell male and female gametes into their environment and reproduce nearly to the end of their $\sim 200$ year life span, essentially exhibiting no PRLS.

To test this hypothesis, we perturbed size and reproductive span parameters in C. elegans, a model system whose long post-reproductive lifespan has been previously assumed to simply be a lab artifact. [Note: to avoid circularity, we held $C$. elegans out of the correlation analysis in Figure 1.] Our model predicts that if either body size ratio or RS/LS ratio are altered, there would be a suboptimal effect on reproduction or lifespan. TGF-b Sma/Mab mutants are defective in their coupling of longevity and reproductive aging: their germline and oocyte quality is maintained, extending reproductive span (Figure 2A), but their somatic tissues age at the same rate as wild-type worms (Figure 2B) [15]. Thus, their somatic integrity does not match the high quality of their germlines [16], and their PRLS is compressed without adjusting their offspring ratio proportionally (in fact, their eggs are the same size as wild-type, but their bodies are smaller, thus increasing their offspring ratio) [72]. The effect of this uncoupling is fatal for the animals in late reproduction: because their reproductive span is so long, TGF-b mutants often die from matricide (internal hatching of offspring, Figure $\mathbf{2 C}$ ) while still reproductive, truncating their reproductive lives (Figure 2D, * indicates matricide). Wild-type worms usually avoid this fate: C. elegans seems to have tied somatic integrity to the offspring ratio, thus tuning post-reproductive lifespan to maximize reproductive span. Further extension of reproductive span without increased somatic integrity results in matricide.

When would the maintenance of somatic integrity extending through late reproduction be important? Limited nutrient conditions, a common situation in the wild, pose such a situation. Dietary restriction extends the lifespan of all animals tested thus far [73]; additionally, dietary restriction delays reproduction [74] (Figure 2E). For example, in mammals, fertilized oocyte implantation can be delayed under low nutrient conditions [75], and in humans this process is modulated through FOXO and Insulin signaling $[76,77]$, which also regulates both lifespan and reproductive span in C. elegans (Figure 2F). In order for reproduction to resume once nutrients become available, the soma must be healthy enough to enable birth, even at advanced ages. Longevity extension, and thus extended PRLS, under dietaryrestricted conditions may simply be the result of the coupling of somatic and reproductive aging that is necessary to allow a plastic reproductive response to varying nutrient conditions.

\section{Discussion}

What prevents evolutionary pressure from bringing somatic aging in synchrony with reproductive aging, if for no other reason than to prevent wasting resources that could go to younger generations? For instance, salmon die shortly after spawning; although not instantaneously after reproduction, several days after a multi-year life represents an excellent matching of the two types of aging-despite at least partially separate genetic and regulatory control [69]. Moreover, in the case of salmon specifically, reproduction follows an exhausting migration and severe lack of nutrients (salmon stop feeding), further accelerating somatic decline and death after reproduction [78]. Indeed, lifespan appears to be influenced by hormonal signals (that are in turn partially environmentally influenced) from the reproductive system. For instance, castration of salmon gonads before development prolongs lifespan significantly [79]. Similar findings have been reported in $C$. elegans, mediated through the DAF-12/Nuclear hormone receptor and DAF-16/FOXO signaling pathways $[80,81]$. Moreover, in humans, the onset of menopause is associated with increased healing time and the rise of cardiovascular disease and other pathologies, and estrogen has been shown to be protective against various health risks-although the mechanisms have not been completely elucidated $[82,83]$. 
What remains, though, is to posit why some organisms live very long after they stop reproducing and could theoretically carry another brood. At least a component of this prolonged PRLS could be explained by the nature of biological anti-aging mechanisms. It has been posited that aging is not caused by environmental damage, but rather by the failure to repair that damage [66]. Thus, by that same reasoning, aging depends partly on that damage occurring. If such damage does not occur or occurs more slowly than expected, then

\section{A}

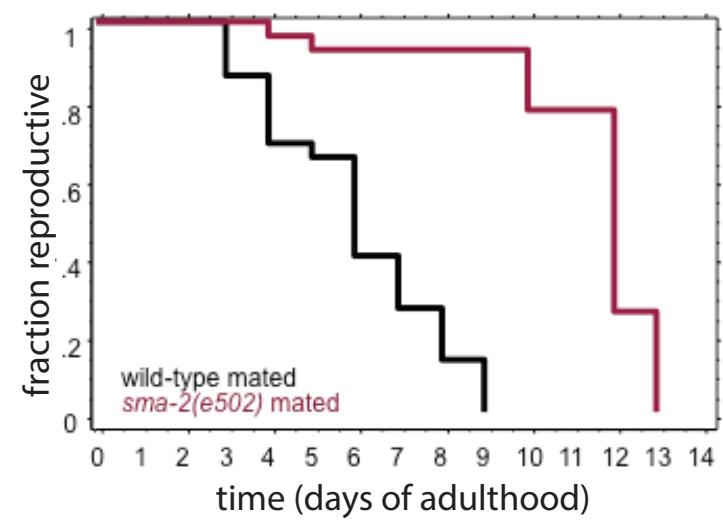

C

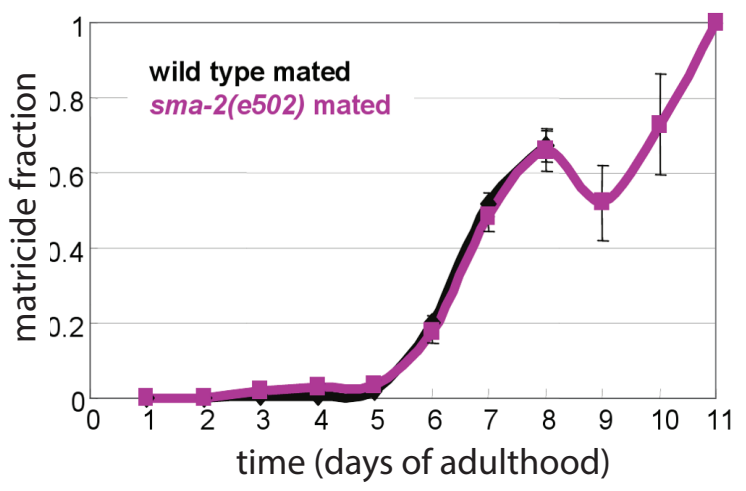

$\mathrm{E}$

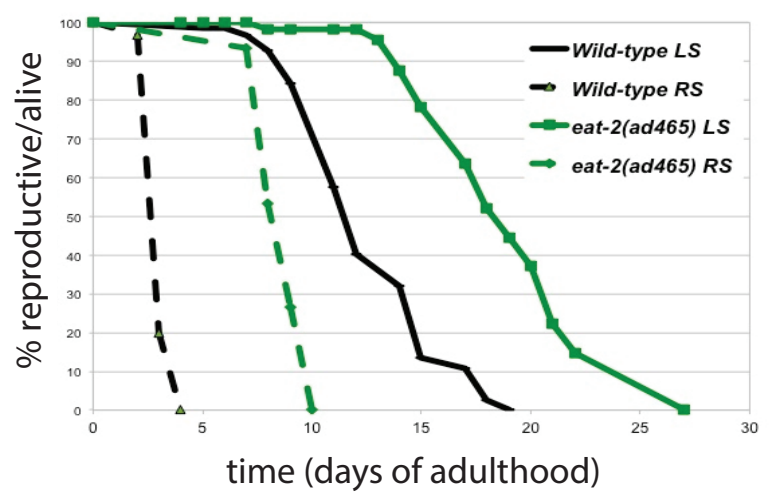

aging will be slowed. The case of Werner's syndrome illustrates; the failure of one such repair mechanism takes years to kill-but eventually it does [84].

On the other hand, in addition to repairing damage to the reproductive tract and even the germ line, reproduction requires "positive control." That is, certain processes (hormonal, regulatory, or otherwise) must be allowed for

B

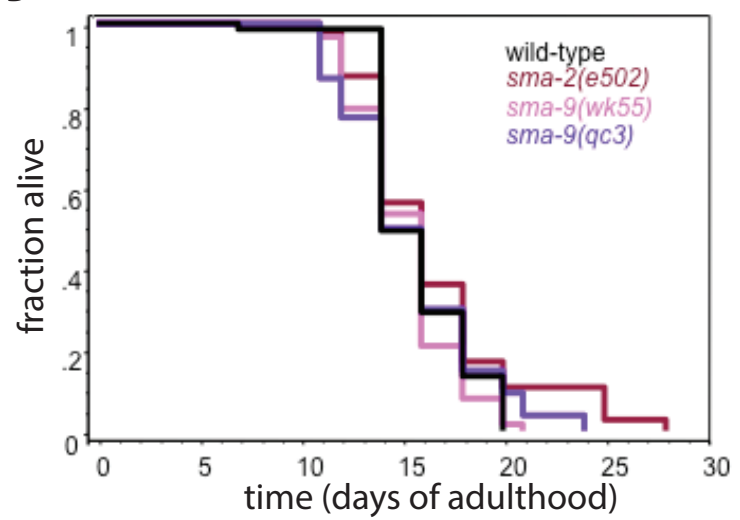

D

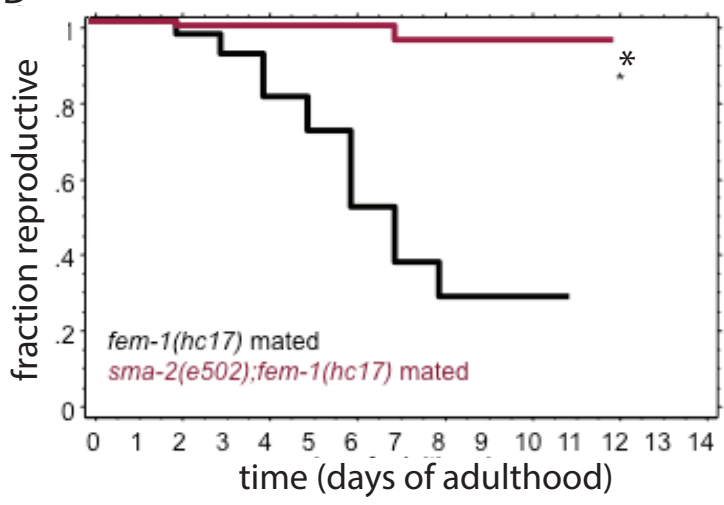

$\mathrm{F}$

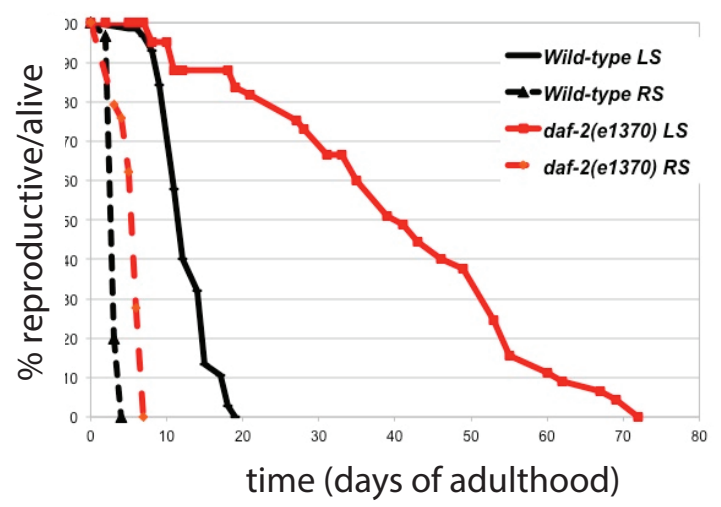

Figure 2. Uncoupling of offspring ratio and reproductive span from longevity results in matricide 
reproduction to proceed. If these prerequisites are not met, reproduction halts and the organism enters reproductive senescence. All that has to occur, then, for reproduction to stop-unlike in general somatic aging-is for some prerequisite process to stop or be damaged severely. In a sense, reproduction is much more sensitive to aging because it is a high-stress endeavor and requires so many relatively independent processes at various levels to act. Moreover, these mechanisms are also subject to much greater selection by evolution as they act earlier in life and are intimately concerned with an organism's evolutionary fitness [85]. Nonetheless, this is not to claim that either type of aging is determined. Medical treatments have intervened in both processes. As witnessed by the dramatic increase in lifespan over the 20th century and the development of in vitro fertilization and general reproductive medicine, both mechanisms of aging can be altered. However, oocyte quality ultimately limits human reproductive span, as in $C$. elegans [69]).

The fact that the simple offspring ratio can correlate parameters across a great number of highly unrelated taxonomic groups, from the most primitive to complex animals, suggests deeper relationships at the genetic and regulatory levels, revealing the intricate connection between reproduction and the structure and parameters of life history. Indeed, previous work has suggested that several factors affect PRLS in less developed organisms in which parental care is a less important factor and social structures differ from those of highly developed mammals [86]. Going forward, it will be essential to develop proxies for predation and parental care $[87,88]$, when appropriate, to account for the remaining variance in PRLS. While parental care may certainly modulate the length of post-reproductive life in some animals, considering offspring size ratio as a proxy for childbirth stress, and PRLS as a byproduct of somatic health during reproduction, offers a new perspective in predicting the post-reproductive lifespan across animal taxa. This model explains the existence of post-reproductive lifespan in animals that do not display parental care, disposing of the need to invoke a "purpose" for PRLS in most species.

\section{Acknowledgements}

We thank Zemer Gitai, Maureen Barr, Daniel Rubenstein, Andrea Bodnar, and members of the Murphy lab for critical discussion of the work, and Shijing Luo and Jasmine Ashraf for assistance with Figure 2.

\section{Author Contributions}

CTM developed the concept; GM carried out all data gathering and analysis; GM and CTM wrote the paper.

\section{Author Information \& Financial Interests Declaration}

Original data and sources are available in Supplemental Information. The authors declare no competing financial interests. Correspondence and requests for materials should be addressed to ctmurphy@princeton.edu.

\section{Abbreviations}

PRLS: Post-Reproductive Lifespan, RS: Reproductive Span, LS: Life span

\section{References}

1. Caspari R, Lee S. (2004) Older age becomes common late in human evolution. Proceedings of the National Academy of Sciences of the United States of America 101: 10895900.

2. Amundsen DW, Diers CJ. (1973) The age of menopause in medieval europe. Human Biology 45: 605-12.

3. Perls TT, Alpert L, Fretts RC. (1997) Middle-aged mothers live longer. Nature 389: 133-133.

4. Cohen AA. (2004) Female post-reproductive lifespan: A general mammalian trait. Biological Reviews of The Cambridge Philosophical Society 79: 733-50.

5. Kirkwood TBL, Shanley DP. (2010) The connections between gerneral and reproductive senescence and the evolutionary basis of menopause. Annals of the New York Academy of Sciences 1204: 21-9.

6. Roger V, Go AS, Lloyd-Jones D, Benjamin EJ, Berry JD, et al. (2012) Heart disease and stroke statistics--2012 update: A report from the american heart association. Circulation 125: e2-e220.

7. Howlader N, Noone AM, Krapcho M, Neyman N, Aminou R, et al. (2012) SEER cancer statistics review, 1975-2009. Bethesda, MD: National Cancer Institute. 
8. Maas AHEM, Franke HR. (2009) Women's health in menopause with a focus on hypertension. Netherlands Heart Journal 17: 68-72.

9. Wu JM, Zelinski MB, Ingram DK, Ottinger MA. (2005) Ovarian aging and menopause: Current theories, hypotheses, and research models. Experimental Biology and Medicine 230: 818-28.

10. Madrigal L, Melendez-Obando M. (2008) Grandmothers' longevity negatively affects daughters' fertility. American Journal of Physical Anthropology 136: 223-9.

11. Turke PW. (1997) Hypothesis: Menopause discourages infanticide and encourages continued investment by agnates. Evolution and Human Behavior 18: 3-13.

12. Hawkes K. (2004) The grandmother effect. Nature 428: 128-9.

13. Hawkes K. (2003) Grandmothers and the evolution of human longevity. American Journal of Human Biology 15: 380-400.

14. Hawkes K, O'Connell JF, Jones NG, Alvarez H, Charnov EL. (1998) Grandmothering, menopause, and the evolution of human life histories. Proceedings of the National Academy of Sciences of the United States of America 95: 1336-9.

15. Luo S, Shaw WM, Ashraf J, Murphy CT. (2009) TGF-beta sma/mab signaling mutations uncouple reproductive aging from somatic aging. PLoS Genetics 5: e1000789.

16. Luo S, Kleemann GA, Ashraf JM, Shaw WM, Murphy CT. (2010) TGF- $\beta$ and insulin signaling regulate reproductive aging via oocyte and germline quality maintenance. Cell 15: 299-312.

17. Hughes SE, Evason K, Xiong C, Kornfeld K. (2007) Genetic and pharmacological factors that influence reproductive aging in nematodes. PLoS genetics 3: e25.

18. Huang C, Xiong C, Kornfeld K. (2004) Measurements of age-related changes of physiological processes that predict lifespan of caenorhabditis elegans. Proceedings of the National Academy of Sciences of the United States of America 101: 8084-9.

19. Austad S, Hazzard DG, Warner HR, Finch CE. (1991) National institution on aging, $\mathrm{NIH}$, workshop on alternative animal models for research on aging: Invertebrates. Experimental Gerontology 26: 432-8.

20. Agh N, Van Stappen G, Bossier P, Sepehri H, Lofti V, et al. (2008) Effects of salinity on survival, growth, reproductive and life span characteristics of artemia populations from urmia lake and neighboring lagoons. Pakistan Journal of Biological Sciences 11: 164-72.

21. Tatar M. (2010) Reproductive aging in invertebrate genetic models. Annals of the New York Academy of Sciences 1204: 149-55.

22. Berrigan D. (1991) The allometry of egg size and number in insects. Oikos 60: 313-21.

23. Schnebel EM, Grossfield J. (1983) A comparison of lifespan characteristics inDrosophila. Experimental Gerontology 18: 325-37.

24. Schnebel EM, Grossfield J. (1988) Antagonistic pleiotropy: An interspecific drosophila comparison. Evolution 42: 306-11.

25. Smith JM, Vida G. (1990) Organizational constraints on the dynamics of evolution. New York, New York: Manchester University Press.

26. Patnaik BK. (1994) Aging in reptiles. Gerontology 40: 20020.

27. R Development Core Team. (2012) R: A language and environment for statistical computing. Vienna, Austria: R Foundation for Statistical Computing.

28. Leisch F, Dimitriadou E. (2010) Mlbench: Machine learning benchmark problems. : R package version 2.1-1.

29. Graffelman J. (2012) Calibrate: Calibration of scatterplot and biplot axes. .

30. Liu G, Rogers J, Murphy CT, Rongo C. (2011) EGF signaling activates the ubiquitin proteasome system to modulate C. elegans lifespan. EMBO Journal 30: 2990-3003.

31. May RM, Rubenstein DI. (1986) Reproductive strategies. In: Austin CR, Short RV, editors. Reproduction in Mammals. Cambridge, UK: Cambridge University Press. pp. 1-23. 
32. de Magalhaes JP, Costa J. (2009) A database of vertebrate longevity records and their relation to other life-history traits. Journal of Evolutionary Biology 22: 1770-4.

33. Cohen AA. (2004) Female post-reproductive lifespan: A general mammalian trait. Biological Reviews of the Cambridge Philosophical Society 79: 733-50.

34. Caro TM, Sellen DW, Parish A, Frank R, Brown DM, et al. (1995) Termination of reproduction in nonhuman and human female primates. International Journal of Primatology 16: 205-20.

35. Oli MK, Dobson FS. (2003) The relative importance of lifehistory variables to population growth rate in mammals: Cole's prediction revisited. American Naturalist 161: 422-40.

36. Hazzard DG, Warner HR, Finch CE. (1991) National institution on aging, $\mathrm{NIH}$, workshop on alternative animal models for research on aging: Introduction. Experimental Gerontology 26: 411-12.

37. Cheal M, Hazzard DG, Warner HR, Finch CE. (1991) National institution on aging, NIH, workshop on alternative animal models for research on aging: Mammals. Experimental Gerontology 26: 412-7.

38. Ottinger MA, Hazzard DG, Warner HR, Finch CE. (1991) National institution on aging, $\mathrm{NIH}$, workshop on alternative animal models for research on aging: Birds. Experimental Gerontology 26: 426-32.

39. Schreibman M, Hazzard DG, Warner HR, Finch CE. (1991) National institution on aging, $\mathrm{NIH}$, workshop on alternative animal models for research on aging: Reptiles and fish. Experimental Gerontology 26: 417-26.

40. Sempier S. (2003) Red sea urchin:Strongylocentrotus franciscanus. 2012.

41. [Anonymous]. (2008) Sea urchin embryology: Gametes. 2012.

42. Loram J, Bodnar A. (2012) Age-related changes in gene expression tissues of the sea urchinStrongylocentrotus purpuratus. Mechanisms of Ageing and Development 2012: 338-47.

43. Rogers-Bennett L. (2007) The ecology ofStrongylocentrotus
franciscanusandStrongylocentrotus purpuratus. In: Lawrence J, editor. Sea Urchins: Biology and Ecology. Amsterdam, Netherlands: Elsevier. pp. 398.

44. Ebert T. (2008) Longevity and lack of senescence in the red sea urchinStrongylocentrotus franciscanus. Experimental Gerontology 43: 734-8.

45. Ebert T, Southon J. (2003) Red sea urchins (Strongylocentrotus franciscanus) can live over 100 years: Confirmation with Abomb $<$ SUP $>14</$ SUP $>$ carbon. Fishery Bulletin, United States 101: 915-22.

46. Sempier S. (2003) Purple sea urchin:Strongylocentrotus purpuratus. 2012.

47. Ebert T. (1967) Negative growth and longevity in the purple sea urchin strongylocentrotus purpuratus (stimpson). Science 157: 557-8.

48. Allen MA, Hassler TJ. (1986) Species profiles: Life histories and environmental requirements of costal fishes and invertebrates (pacific southwest)--chinook salmon. U S Fish Wildlife Service Biological Reports : 26.

49. Beacham TD, Murray CB. (1993) Fecundity and egg size variation in north american pacific salmon (Oncorhynchus). Journal of Fish Biology 42: 485-508.

50. Nicomekl Enhancement Society. (2012) Our salmon species / life cycle. 2012.

51. NOAA Fisheries Office of Protected Resources. (2012) Chinook salmon (Oncorhynchus tshawytscha). 2012.

52. NOAA Fisheries Office of Protected Resources. (2012) Coho salmon (Oncorhynchus kisutch). 2012.

53. NOAA Fisheries Office of Protected Resources. (2012) Chum salmon (Oncorhynchus keta). 2012.

54. California Foundation for Agriculture in the Classroom. (2011) Commodity fact sheet: Eggs. 2012.

55. Farm Animal Shelters. (2007) Farm animal care: Chicken care. 2012.

56. Hermes JC. (2003) Why did my chickens stop laying? PNW 565: 1-2. 
57. Peres MB, Vooren CM. (1991) Sexual development, reproductive cycle, and fecundity of the school SharkGaleorhinus galeusoff southern brazil. Fishery Bulletin, United States 89: 655-67.

58. Baremore IE. (2010) Reproductive aspects of the atlantic angel sharkSquatina dumeril. Journal of Fish Biology 76: 1682-95.

59. Walker TI, Cavanagh RD, Stevens JD, Carlisle AB, Chiaramonte GE, et al. (2006) Galeorhinus galeus. 2013.

60. Food and Agricultural Organization of the United Nations. (1984) Species fact sheets:Galeorhinusgaleus. 2013.

61. Platt SG, Resetar A, Stuart B, L. (2004) Maximum clutch size of the american alligator. Florida Field Naturalist 32: 102-6.

62. San Diego Zoo. (2013) San diego zoo's animal bytes: Alligator \& crocodile. 2013.

63. Smithsonian National Zoological Park. (2012) Fact sheets: American alligator. 2013.

64. Moorad JA, Promislow DEL, Fiesness N, Miller RA. (2012) A comparative assessment of univariate longevity measures using zoological animals records. Aging Cell 11: 940-9.

65. Shapovalov L, Taft A. (1954) The life histories of the steelhead rainbow trout (salmo gairdneri gairdneri) and silver salmon (oncorhynchus kisutch) with special reference to waddell creek, california, and recommendations regarding their management. State of California Department of Fish and Game Fish Bulletin 98: 1-375.

66. Williams GC. (1957) Pleiotropy, natural selection, and the evolution of senescence. Evolution 11: 398-411.

67. Pagel MD, Harvey PH. (1988) Recent developments in the analysis of comparative data. Quarterly Review of Biology : 413-40.

68. Garland T, Harvey PH, Ives AR. (1992) Procedures for the analysis of comparative data using phylogenetically independent contrasts. Systematic Biology : 18-32.
69. Luo S, Murphy CT. (2011) Caenorhabditis elegans reproductive aging: Regulation and underlying mechanisms. Genesis 49: 53-65.

70. Reznick D, Bryant M, Holmes D. (2006) The evolution of senescence and post-reproductive lifespan in guppies (poecilia reticulata). PloS Biology 4: e7-e7.

71. Loudon I. (1993) Death in childbirth: An international study of maternal care and maternal mortality 18001950. New York, New York: Oxford University Press.

72. Savage-Dunn C, Tokarz R, Wang H, Cohen S, Giannikas C, et al. (2000) SMA-3 smad has specific and critical functions in DBL-1/SMA-6 TGFbeta-related signaling. Developmental Biology 223: 70-6.

73. Robertson L, Mitchell JR. (2013) Benefits of short-term dietary restriction in mammals. Experimental Gerontology In Press.

74. Selesniemi K, Lee H, Tilly JL. (2008) Moderate caloric restriction initiated in rodents during adulthood sustains function of the female reproductive axis into advanced chronological age. Ageing Cell 7: 622-9.

75. Ptak G, Tacconi E, Czernik M, Toschi P, Modlinski J, et al. (2012) Embryonic diapaise is conserved across mammals. PLoS ONE 7: e33027.

76. Grinsted J, Avery B. (1996) A sporadic case of delayed implantation after in-vitro fertilization in the human? Human Reproduction 11: 651-4.

77. Sim C, Denlinger DL. (2008) Insulin signaling and FOXO regulate the overwintering diapause of the mosquitoCulex pipiens. Proceedings of the National Academy of Sciences of the United States of America 105: $6777-81$.

78. Dickhoff WW. (1989) Salmonids and annual fishes: Death after sex. In: Scanes CJ, Schriebman MP, editors. Development, maturation, and senescence of neuroendocrine systems. New York, NY: Academic. pp. 253-66.

79. Robertson OH. (1961) Prolongation of the life span of kokanee salmon (oncorhynchus nerka kennerlyi) by castration before beginning of gonad development. Proceedings Biological Sciences / The Royal Society 47: 609-21. 
80. Berman JR, Kenyon C. (2006) Germ-cell loss extends C. elegans life span through regulation of DAF-16 by kri-1 and lipophilic-hormone signaling. Cell 124: 1055-68.

81. Hsin H, Kenyon C. (1999) Signals from the reproductive system regulate the lifespan of C. elegans. Nature 399: 362-6.

82. Emmerson E, Hardman MJ. (2012) The role of estrogen deficiency in skin ageing and wound healing. Biogerontology 13: 3-20.

83. Aviv A. (2007) Cardiovascular diseases, aging and the gender gap in the human longevity. Journal of the American Society of Hypertension 1: 185-8.

84. Finch CE. (2010) Evolution in health and medicine sackler colloquium: Evolution of the human lifespan and diseases of aging: Roles of infection, inflammation, and nutrition. Proceedings of the National Academy of Sciences of the United States of America 107 Suppl: 1718-24.

85. Kirkwood TB, Rose MR. (1991) Evolution of senescence: Late survival sacrificed for reproduction. Proceedings Biological Sciences / the Royal Society 332: 15-24.

86. Finch CE, Holmes DJ. (2010) Ovarian aging in developmental and evolutionary contexts. Annals of the New York Academy of Sciences 1204: 82-94.

87. Foote AD. (2008) Mortality rate acceleration and postreproductive lifespan in matrilineal whale species. Biology Letters 4: 189-91.

88. Hendry AP, Morbey YE, Berg OK, Wenburg JK. (2004) Adaptive variation in senescence: Reproductive lifespan in a wild salmon population. Proceedings Biological Sciences / The Royal Society 271: 259-66.

\section{Figure Legends}

Figure 1. Post-reproductive life span correlates with offspring ratio. A: Scheme of life history parameters considered distinguishing between reproductive and somatic aging. PRLS = "post-reproductive life span" (from reproductive senescence to death). B: Log PRLS is positively correlated with log of the offspring ratio. Regression parameters: Intercept (coefficient estimate: -0.160 , standard error: 0.918, t-value: -0.175 , and p-value: 0.865$)$ and log offspring ratio: (coefficient estimate: 0.469 , standard error: 0.0809 , t-value: 5.80 , and p-value: 0.000174 ) on a residual standard error of 1.93, degrees of freedom of $10, R^{2}$ of 0.771 , and an F-statistic of 33.58 on 1 and 10 degrees of freedom. C: log PRLS is negatively correlated with Litter Size, and D: log Offspring Ratio is also negatively correlated with log Litter Size. See Table 1 for specific regression parameters. All statistical analyses were performed in the $R$ statistical analysis package (64-bit, version 2.14.2). See Supplemental Methods for species information.

Figure 2. Uncoupling of offspring ratio and reproductive span from longevity results in matricide. A: The reproductive span of the TGF-b mutant sma-2 is extended relative to wildtype $C$. elegans, but the life span of TGF-b mutants (sma-2 and sma-9) is not extended (B). C: Matricide rate of TGF-b mutants (sma-2, sma-9, and daf-4) increases with age. D: Matricide $\left({ }^{*}\right)$ causes TGF-b mutant worms to die while still reproductive. (fem-1 renders the worms spermless, so that all progeny are the result of mating.) E, F. The dietary restriction model eat-2 and the Insulin/IGF-1-like receptor mutant daf-2 both have extended reproductive span (RS) and life span (LS). All figures are adapted from Luo, et al. 2009.

\section{Supplemental Information}

Supplemental Table 1. A summary of the regressions performed attempting to relate various parameters to PRLS among a sample of mammals. While other variables could explain around $10 \%$ of the variance in PRLS, offspring ratio performed the best (IMR was excluded because there were only 7 data points in the regression versus Offspring Ratio's 86.). Nonetheless, litter size and the proportion of life spent in "childhood" (for both males and females) also seem to explain a similar proportion of the variance.

Supplemental Table 2. Summary of the regressions relating various parameters to PRLS among a sample of mammals and a bird, sorted by $R^{2}$ value. While other variables could explain around $10 \%$ of the variance in PRLS, offspring ratio performed the best. Litter size and the proportion of life spent in "childhood" (for both males and females) explain a similar proportion of the variance. Too few observations of Mortality Rate Doubling time (7) and Increase in Mortality Rate (6) were available to reach significance.

Supplemental Table 3. Summary of data sources. 
Supplemental Figure 1. Linear regression of PRLS vs. various variables for 85 mammals distributed across various families and orders. Linear regressions were constructed based on the logarithms of the variable offspring ratio. A: PRLS is positively correlated with log of offspring ratio. Regression parameters: Intercept (coefficient estimate: 0.217, standard error: 0.0613, $\mathrm{t}$-value: 3.54 , and $p$-value: $<0.000659$ ) and log offspring ratio: (coefficient estimate: -0.0522 , standard error: 0.0175 , tvalue: -2.98 , and $p$-value: 0.00378 ) on a residual standard error of 0.200 , degrees of freedom of $83, R^{2}$ of 0.0956 , and an F-statistic of 8.88 on 1 and 83 degrees of freedom. B, C: a sampling of regressions of PRLS against other statistically significant variables: average litter size and female maturity proportion. D-F: a sampling of regressions of PRLS against other statistically non-significant variables: litter size-adjusted offspring ratio, weaning/adult weights, and metabolic rate, in that order. See Datatable 1 for specific regression parameters. Mammals from the following families are represented (see supplement for detailed information on species): Bovidae, Cervidae, Suidae, Tayassuidae, Canidae, Felidae, Herpestidae, Mephitidae, Otariidae, Phocidae, Ursidae, Delphinidae, Phyllostomidae, Rhinolophidae, Vespertilionidae, Dasyuridae, Leporidae, Equidae, Rhinocerotidae, Callitrichidae, Cebidae, Cercopithecidae, Hominidae, Castoridae, Chinchillidae, Dipodidae, Echimyidae, Muridae, Sciuridae, and Trichechidae. All statistical analyses were performed in the $\mathrm{R}$ statistical analysis package (64-bit, version 2.14.2).
Supplemental Figure 2. The linear regression of PRLS with litter size-adjusted offspring ratio for the all-animal sample. While the general trend remains (a positive correlation), statistical significance and the ability to explain the variance of the data $\left(R^{2}\right)$ are less than without litter size. Regression of PRLS against offspring ratio and litter size yield similar results. All statistical analyses were performed in the $R$ statistical analysis package (64-bit, version 2.14.2).

Supplemental Figure 3. The Partial Regression Plot of the residuals of PRLS vs. Birth Weight Regression and PRLS vs. Adult Weight Regression for 31 families of placental mammals, 1 family of marsupials, and 1 family of birds. The residuals of the separate regressions (PRLS vs. Birth Weight and PRLS vs. Adult Weight) were plotted against each other to extract any natural groupings with respect to PRLS. While the bird family (Corvidae) was indistinguishable from the placental mammals, the marsupial family (Dasyuridae) marked in red readily separated from the placentals in the top right hand corner. In addition, a group of diverse families (marked in blue), including Manatees (Trichechidae), Chinchillas (Chinchillidae), and New World Monkeys, appear to separate out in the bottom left hand corner. Key: see Data Table 1 (the families represented are stated in Supplemental Figure 1, with the addition of Corvidae).

\begin{tabular}{|c|c|c|c|c|c|c|c|}
\hline \multicolumn{8}{|c|}{ Regressions among All Species } \\
\hline y-axis ${ }^{\dagger}$ & $x$-axis ${ }^{\dagger}$ & $\mathbf{R}^{\mathbf{2}}$ & $\begin{array}{c}\text { Coefficient } \\
\text { Estimate }\end{array}$ & $\begin{array}{c}\text { Coefficient } \\
\text { Standard } \\
\text { Error }\end{array}$ & p-value & $\begin{array}{c}\text { Residual } \\
\text { Standard } \\
\text { Error }\end{array}$ & $\begin{array}{c}\text { Degrees of } \\
\text { Freedom }\end{array}$ \\
\hline PRLS & Litter Size & 0.869 & -0.823 & 0.101 & $1.03 * 10^{-5}$ & 1.46 & 10 \\
\hline $\begin{array}{l}\text { Offspring } \\
\text { Ratio }\end{array}$ & Litter Size & 0.781 & -1.46 & 0.245 & 0.000138 & 3.53 & 10 \\
\hline PRLS & Offspring Ratio & 0.771 & 0.469 & 0.0809 & 0.000174 & 1.93 & 10 \\
\hline PRLS & Litter-Adjusted Offspring Ratio & 0.332 & 0.565 & 0.254 & 0.0500 & 3.29 & 10 \\
\hline PRLS & Maturity Proportion & 0.0846 & 0.932 & 0.969 & 0.359 & 3.85 & 10 \\
\hline
\end{tabular}

Table 1. A summary of the regressions relating various parameters to PRLS among a sample of species. Note that litter size and offspring ratio are highly correlated but inversely related. 


\begin{tabular}{|c|c|c|c|c|c|c|}
\hline \multicolumn{7}{|c|}{ Supplemental Table 1: Regressions of Life History and Metabolic Variables (Mammals) } \\
\hline Variable $^{+}$ & $\mathbf{R}^{\mathbf{2}}$ & $\begin{array}{l}\text { Coefficient } \\
\text { Estimate }\end{array}$ & $\begin{array}{c}\text { Coefficient } \\
\text { Standard } \\
\text { Error }\end{array}$ & p-value & $\begin{array}{c}\text { Residual } \\
\text { Standard } \\
\text { Error }\end{array}$ & $\begin{array}{l}\text { Degrees of } \\
\text { Freedom }\end{array}$ \\
\hline $\mathrm{IMR}^{\ddagger}$ (per year) & 0.272 & 0.0554 & 0.406 & 0.230 & 0.128 & 5 \\
\hline Offspring Ratio & 0.1135 & 0.0518 & 0.0158 & 0.00152 & 0.179 & 84 \\
\hline Litter Size & 0.0929 & 0.0945 & 0.0322 & 0.00432 & 0.199 & 84 \\
\hline $\begin{array}{l}\text { Female Maturity } \\
\text { Proportion }\end{array}$ & 0.0861 & -0.123 & 0.0438 & 0.0061 & 0.200 & 84 \\
\hline $\begin{array}{l}\text { Male Maturity } \\
\text { Proportion }\end{array}$ & 0.0844 & -0.119 & 0.0460 & 0.0114 & 0.206 & 73 \\
\hline Growth Rate (per day) & 0.0606 & 0.0364 & 0.0219 & 0.103 & 0.206 & 43 \\
\hline $\begin{array}{l}\text { Litter Size-Adjusted } \\
\text { Offspring Ratio }\end{array}$ & 0.0278 & -0.0328 & 0.0211 & 0.125 & 0.2059 & 84 \\
\hline Litters per Year & 0.0231 & 0.0509 & 0.0392 & 0.199 & 0.199 & 71 \\
\hline $\begin{array}{l}\text { Weaning Weight / } \\
\text { Adult Weight }\end{array}$ & 0.0217 & -0.0405 & 0.0373 & 0.283 & 0.207 & 53 \\
\hline Gestation Proportion $^{\ddagger}$ & 0.0207 & -0.208 & 0.156 & 0.187 & 0.819 & 84 \\
\hline Weaning Proportion & 0.0184 & -0.0394 & 0.0330 & 0.237 & 0.209 & 76 \\
\hline Birth Weight (g) & 0.0166 & -0.00820 & 0.00689 & 0.238 & 0.207 & 84 \\
\hline Body Temperature $^{\ddagger}(\mathrm{K})$ & 0.0130 & 0.0942 & 0.184 & 0.614 & 0.960 & 20 \\
\hline $\mathrm{MRDT}^{\ddagger}$ (years) & 0.00542 & -0.00141 & 0.00780 & 0.862 & 0.138 & 6 \\
\hline Metabolic Rate (W) & 0.00291 & -0.00512 & 0.0165 & 0.758 & 0.239 & 33 \\
\hline Weaning Weight (g) & 0.00117 & 0.00256 & 0.0102 & 0.804 & 0.210 & 53 \\
\hline Adult Weight (g) & 0.000140 & -0.000740 & 0.00683 & 0.914 & 0.209 & 84 \\
\hline \multicolumn{7}{|c|}{$\begin{array}{l}{ }^{\dagger} \text { Logarithmic transformation of variables unless noted. See supplement for definitions of variables. } \\
{ }^{\ddagger} \text { For Gestation Proportion, both variables with logarithmically transformed. For IMR and MRDT per } \\
\text { year, no logarithmic transformation was performed. For Body Temperature, PRLS was } \\
\text { logarithmically transformed. }\end{array}$} \\
\hline
\end{tabular}

Supplemental Table 1. A summary of the regressions performed attempting to relate various parameters to PRLS among a sample of mammals. While other variables could explain around $10 \%$ of the variance in PRLS, offspring ratio performed the best (IMR was excluded because there were only 7 data points in the regression versus Offspring Ratio's 86.). Nonetheless, litter size and the proportion of life spent in "childhood" (for both males and females) also seem to explain a similar proportion of the variance. 


\begin{tabular}{|c|c|c|c|c|c|c|}
\hline Variable $^{\dagger}$ & $\mathbf{R}^{\mathbf{2}}$ & $\begin{array}{l}\text { Coefficient } \\
\text { Estimate }\end{array}$ & $\begin{array}{l}\text { Coefficient } \\
\text { Standard } \\
\text { Error }\end{array}$ & p-value & $\begin{array}{c}\text { Residual } \\
\text { Standard } \\
\text { Error }\end{array}$ & $\begin{array}{c}\text { Degrees of } \\
\text { Freedom }\end{array}$ \\
\hline Offspring Ratio & 0.0972 & -0.0526 & 0.0176 & 0.00378 & 0.199 & 83 \\
\hline Litter Size & 0.0909 & 0.0941 & 0.0327 & 0.00504 & 0.200 & 83 \\
\hline Female Maturity Proportion & 0.0882 & -0.125 & 0.0441 & 0.00577 & 0.200 & 83 \\
\hline Male Maturity Proportion & 0.0858 & -0.120 & 0.0463 & 0.0113 & 0.207 & 72 \\
\hline Growth Rate (per day) & 0.0573 & 0.0379 & 0.0237 & 0.118 & 0.208 & 42 \\
\hline Litter Size-Adjusted Offspring Ratio & 0.0304 & -0.0345 & 0.0214 & 0.110 & 0.207 & 83 \\
\hline Litters per Year & 0.0231 & 0.0507 & 0.0395 & 0.203 & 0.200 & 70 \\
\hline Weaning Weight / Adult Weight & 0.0217 & -0.0405 & 0.0373 & 0.283 & 0.207 & 53 \\
\hline Gestation Proportion $^{\ddagger}$ & 0.0181 & -0.199 & 0.161 & 0.219 & 0.824 & 83 \\
\hline Weaning Proportion & 0.0184 & -0.0394 & 0.0330 & 0.237 & 0.209 & 76 \\
\hline Birth Weight (g) & 0.0153 & -0.00794 & 0.00699 & 0.259 & 0.208 & 83 \\
\hline Body Temperature $^{\ddagger}(\mathrm{K})$ & 0.0130 & 0.0942 & 0.184 & 0.614 & 0.960 & 20 \\
\hline Metabolic Rate (W) & 0.00291 & -0.00512 & 0.0165 & 0.758 & 0.239 & 33 \\
\hline Weaning Weight (g) & 0.00117 & 0.00256 & 0.0102 & 0.804 & 0.210 & 53 \\
\hline Adult Weight (g) & 0.0000258 & -0.000321 & 0.00693 & 0.963 & 0.210 & 83 \\
\hline \multicolumn{7}{|c|}{$\begin{array}{l}{ }^{\dagger} \text { Logarithmic transformation of variables unless noted. See supplement for definitions of variables. } \\
\text { fFor Gestation Proportion, both variables with logarithmically transformed. } \\
\text { For Body Temperature, PRLS was logarithmically transformed. }\end{array}$} \\
\hline
\end{tabular}

Supplemental Table 2. A summary of the regressions relating various parameters to PRLS among a sample of mammals and a bird, sorted by $R^{2}$ value. While other variables could explain around $10 \%$ of the variance in PRLS, offspring ratio performed the best. Litter size and the proportion of life spent in "childhood" (for both males and females) explain a similar proportion of the variance. Too few observations of Mortality Rate Doubling time (7) and Increase in Mortality Rate (6) were available to reach significance. 


\begin{tabular}{|c|c|c|}
\hline Scientific Name & Common Name & Reference \\
\hline $\begin{array}{l}\text { Mammals + Some } \\
\text { Birds }\end{array}$ & & $\begin{array}{l}\text { de Magalhaes and Costa, } 2009 \\
\text { Caro et al., } 1995 \\
\text { Cohen, } 2004 \\
\text { Oli and Dobson, } 2003\end{array}$ \\
\hline $\begin{array}{l}\text { Strongylocentrotus } \\
\text { franciscanus }\end{array}$ & Red Sea Urchin & $\begin{array}{l}\text { Anonymous, } 2008 \\
\text { Bodnar, Personal Communication } \\
\text { Loram and Bodnar, } 2012 \\
\text { Rogers-Bennett, } 2007 \\
\text { Sempier, 2003b }\end{array}$ \\
\hline $\begin{array}{l}\text { Strongylocentroltus } \\
\text { purpuratus }\end{array}$ & $\begin{array}{l}\text { Purple Sea } \\
\text { Urchin }\end{array}$ & $\begin{array}{l}\text { Anonymous, } 2008 \\
\text { Bodnar, Personal Communication } \\
\text { Loram and Bodnar, } 2012 \\
\text { Rogers-Bennett, } 2007 \\
\text { Sempier, 2003a }\end{array}$ \\
\hline $\begin{array}{l}\text { Oncorhynchus } \\
\text { tshawytscha }\end{array}$ & Chinook Salmon & $\begin{array}{l}\text { Allen and Hassler, } 1986 \\
\text { Beacham and Murray, } 1993 \\
\text { Nicomekl Enhancement Society, } 2012 \\
\text { NOAA Fisheries Office of Protected Resources, 2012a }\end{array}$ \\
\hline Oncorhynchus keta & Chum Salmon & $\begin{array}{l}\text { Beacham and Murray, } 1993 \\
\text { Nicomekl Enhancement Society, } 2012 \\
\text { NOAA Fisheries Office of Protected Resources, 2012b }\end{array}$ \\
\hline $\begin{array}{l}\text { Oncorhynchus } \\
\text { kisutch }\end{array}$ & Coho Salmon & $\begin{array}{l}\text { Beacham and Murray, } 1993 \\
\text { Nicomekl Enhancement Society, } 2012 \\
\text { NOAA Fisheries Office of Protected Resources, 2012c }\end{array}$ \\
\hline $\begin{array}{l}\text { Gallus gallus } \\
\text { domesticus }\end{array}$ & $\begin{array}{l}\text { Leghorn-Breed } \\
\text { Chicken }\end{array}$ & $\begin{array}{l}\text { California Foundation for Agriculture in the Classroom, } 2011 \\
\text { Farm Animal Shelters, } 2007 \\
\text { Hermes, } 2003\end{array}$ \\
\hline Mabuya buettneri & African Skink & $\begin{array}{l}\text { Patnaik, } 1994 \\
\text { Smith and Vida, } 1990\end{array}$ \\
\hline $\begin{array}{l}\text { Drosophila } \\
\text { Melanogaster }\end{array}$ & $\begin{array}{l}\text { Fruit } \\
\text { Fly/Drosophila }\end{array}$ & $\begin{array}{l}\text { Berrigan, } 1991 \\
\text { Schnebel and Grossfield, } 1983 \\
\text { Schnebel and Grossfield, } 1988 \\
\text { Tatar, } 2010\end{array}$ \\
\hline Galeorhinus galeus & School Shark & $\begin{array}{l}\text { Baremore, } 2010 \\
\text { Food and Agricultural Organization of the United Nations, } \\
1984 \\
\text { Peres and Vooren, } 1991 \\
\text { Walker et al., } 2006\end{array}$ \\
\hline $\begin{array}{l}\text { Alligator } \\
\text { mississippiensis }\end{array}$ & $\begin{array}{l}\text { American } \\
\text { Alligator }\end{array}$ & $\begin{array}{l}\text { Platt et al., } 2004 \\
\text { San Diego Zoo, } 2013 \\
\text { Smithsonian National Zoological Park, } 2012\end{array}$ \\
\hline $\begin{array}{l}\text { Ornithorhynchus } \\
\text { anatinus }\end{array}$ & $\begin{array}{l}\text { Duck-Billed } \\
\text { Platypus }\end{array}$ & $\begin{array}{l}\text { Cromer, } 2004 \\
\text { Hall, } 1999 \\
\text { Ojo, } 2012\end{array}$ \\
\hline
\end{tabular}


bioRxiv preprint doi: https://doi.org/10.1101/048835; this version posted April 15, 2016. The copyright holder for this preprint (which was not certified by peer review) is the author/funder. All rights reserved. No reuse allowed without permission.

A

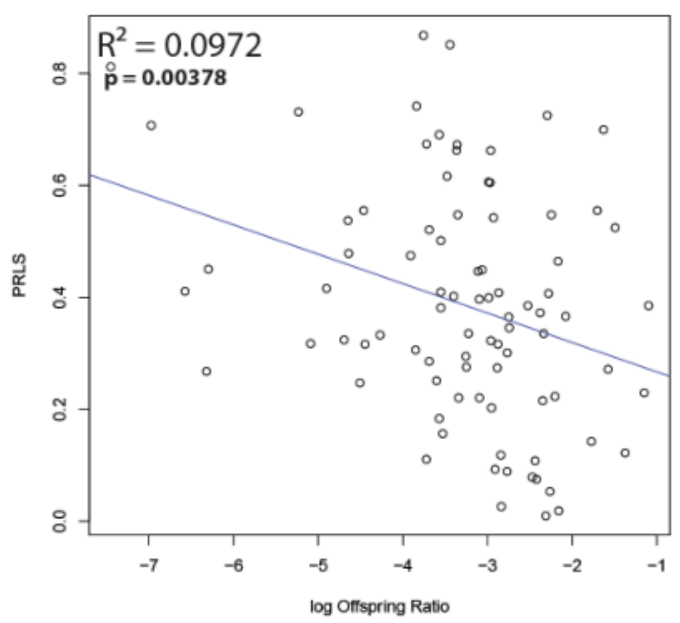

C

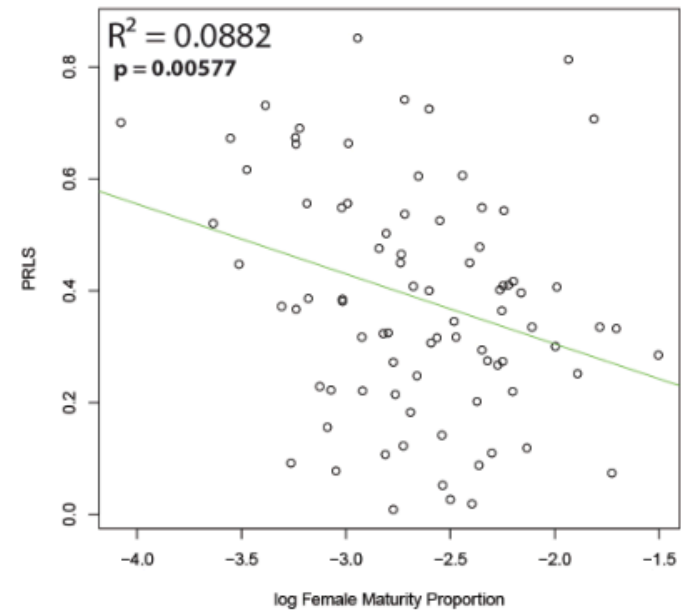

$E$

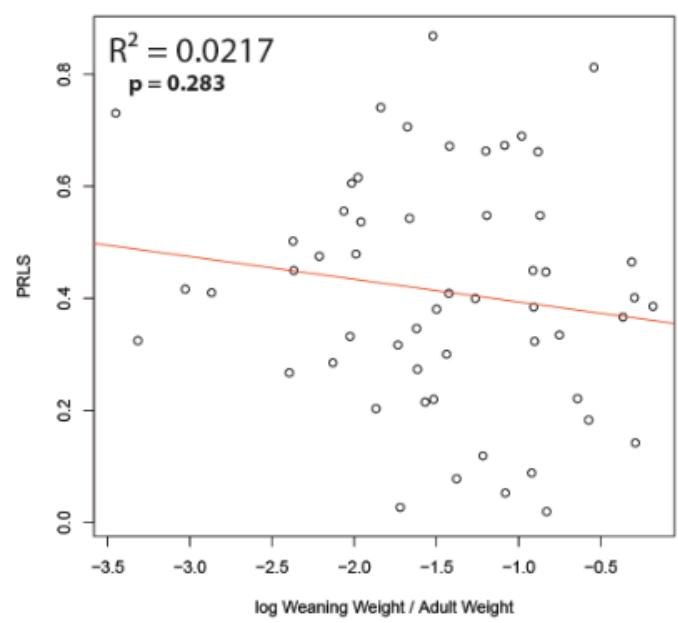

Maliha \& Murphy - preprint version -www.biorxiv.org

B

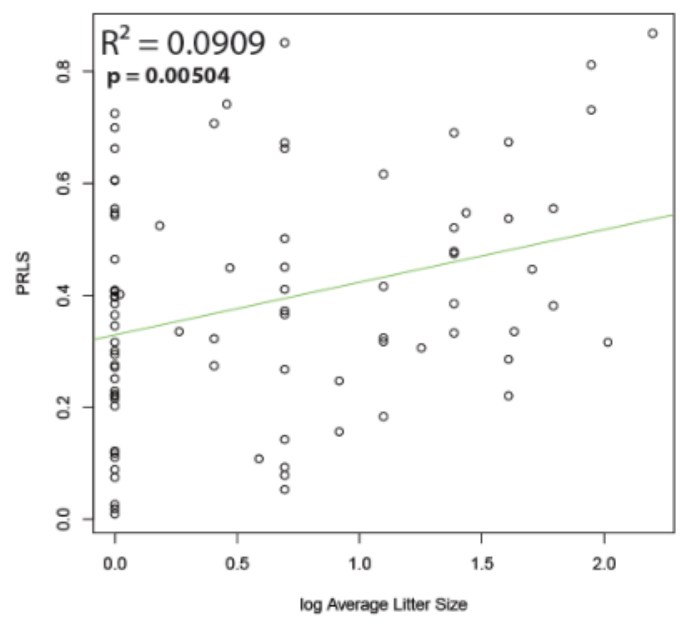

D

Mammalian PRLS vs. Litter Size-Adjusted Offspring Ratio

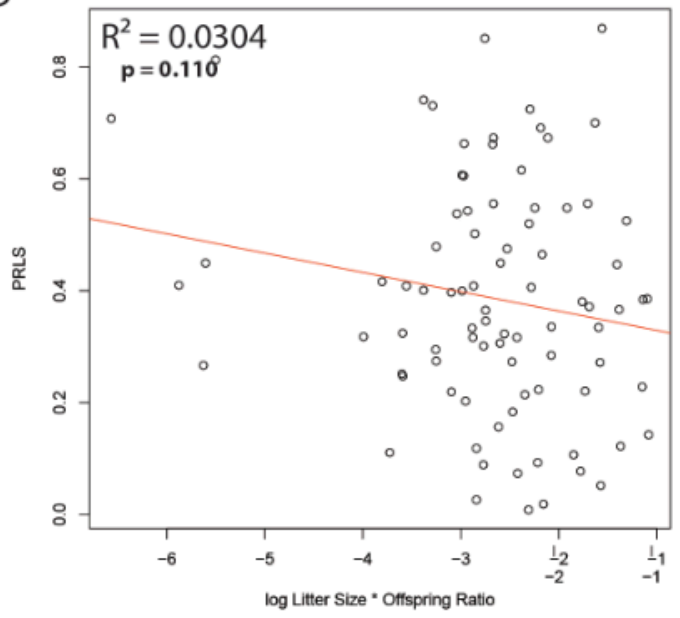

$\mathrm{F}$

PRLS vs. Metabolic Rate

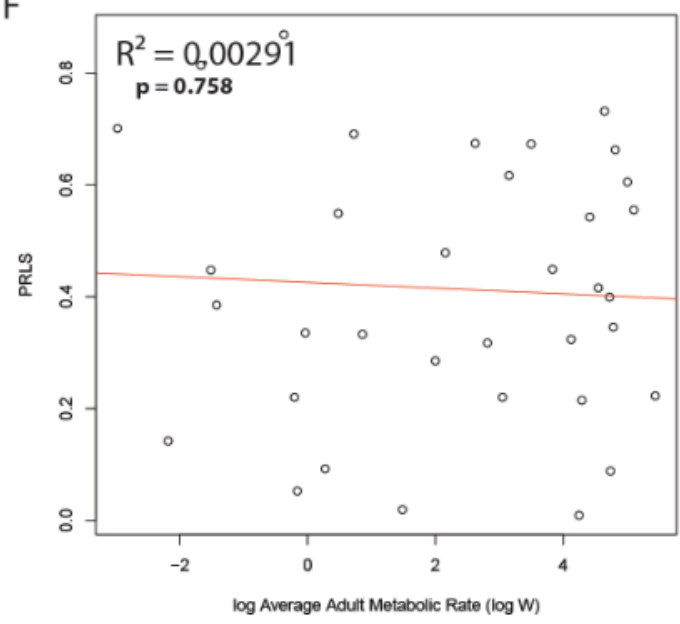

Supplemental Figure 1 
PRLS vs. Litter Size-Adjusted Offspring Ratio

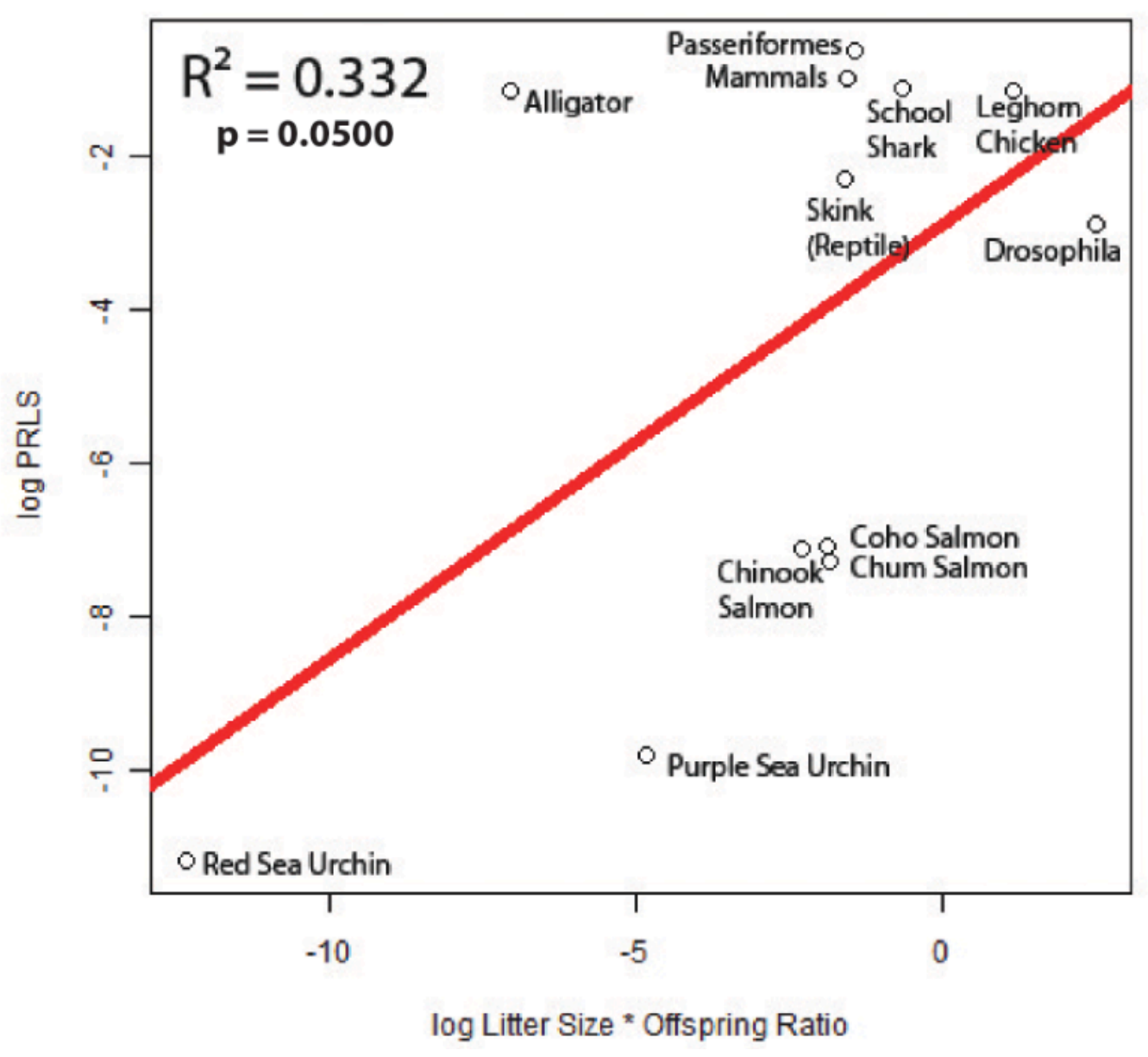

Supplemental Figure 2 


\section{Partial Regression Plot: Family Level}

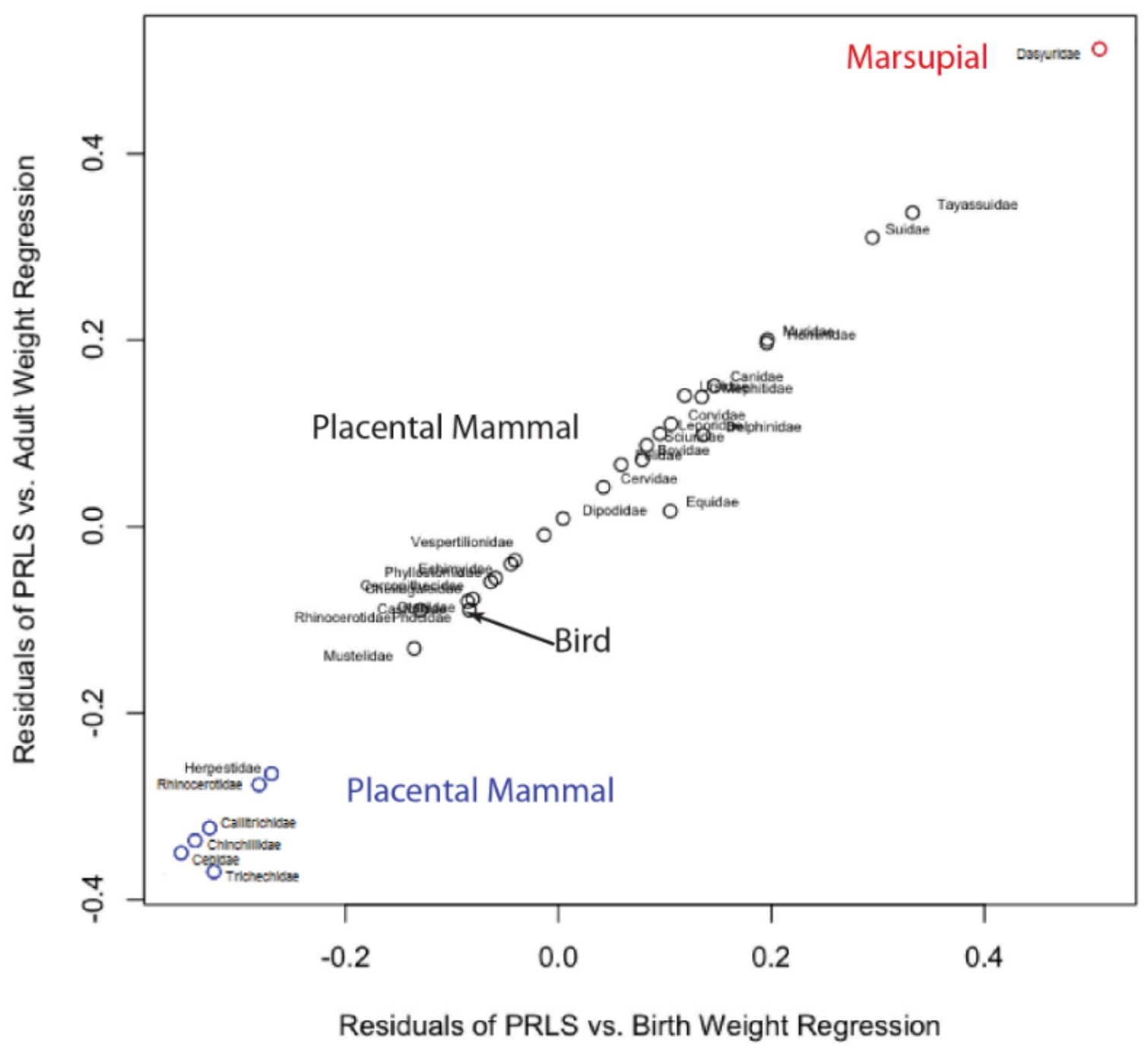

Supplemental Figure 3 
bioRxiv preprint doi: https://doi.org/10.1101/048835; this version posted April 15, 2016. The copyright holder for this preprint (which was not

Datatable 1 certified by peer review) is the author/funder. All rights reserved. No reuse allowed without permission.

\begin{tabular}{|c|c|c|c|c|c|c|c|c|}
\hline Order & Family & Genus & Species & Common Name & $\begin{array}{l}\text { Days to } \\
\text { Reach } \\
\text { Female } \\
\text { Maturity }\end{array}$ & $\begin{array}{l}\text { Female Maturity } \\
\text { Proportion }\end{array}$ & $\begin{array}{l}\text { Days to } \\
\text { Reach Male } \\
\text { Maturity }\end{array}$ & $\begin{array}{l}\text { Male Maturity } \\
\text { Proportion }\end{array}$ \\
\hline Artiodactyla & Bovidae & Syncerus & caffer & African buffalo & 1475 & 0.135607245 & 1674 & 0.153902731 \\
\hline Perissodactyla & Equidae & Equus & asinus & African wild ass & 708 & 0.041270767 & 1005 & 0.058583503 \\
\hline Rodentia & Castoridae & Castor & canadensis & American beaver & 639 & 0.074815595 & 639 & 0.074815595 \\
\hline Carnivora & Ursidae & Ursus & americanus & American black bear & 1278 & 0.102981467 & 1278 & 0.102981467 \\
\hline Carnivora & Phocidae & Pusa & sibirica & Baikal seal & 2129 & 0.104158513 & 2557 & 0.125097847 \\
\hline Carnivora & Herpestidae & Mungos & mungo & Banded mongoose & 289 & 0.045504645 & & \\
\hline Chiroptera & Vespertilionidae & Eptesicus & fuscus & Big brown bat & 547 & 0.07887527 & 730 & 0.105263158 \\
\hline Artiodactyla & Bovidae & Ovis & canadensis & Bighorn sheep & 707 & 0.094028461 & 749 & 0.09961431 \\
\hline Rodentia & Sciuridae & Cynomys & Iudovicianus & Black-tailed prairie dog & 730 & 0.181818182 & 730 & 0.181818182 \\
\hline Artiodactyla & Bovidae & Connochaetes & taurinus & Blue wildebeest & 411 & 0.046338576 & 912 & 0.102824285 \\
\hline Carnivora & Felidae & Lynx & rufus & Bobcat & 365 & 0.030959752 & 730 & 0.061919505 \\
\hline Primates & Cercopithecidae & Macaca & radiata & Bonnet macaque & 1295 & 0.11826484 & 1795 & 0.163926941 \\
\hline Dasyuromorphia & Dasyuridae & Antechinus & stuartii & Brown antechinus & 285 & 0.144596651 & 285 & 0.144596651 \\
\hline Carnivora & Ursidae & Ursus & arctos & Brown bear and grizzly bear & 1313 & 0.089931507 & 1313 & 0.089931507 \\
\hline Perissodactyla & Equidae & Equus & burchellii & Burchell's zebra & 900 & 0.064888248 & 900 & 0.064888248 \\
\hline Sirenia & Trichechidae & Trichechus & manatus & Caribbean manatee & 1278 & 0.062524462 & 913 & 0.044667319 \\
\hline Artiodactyla & Cervidae & Rangifer & tarandus & Caribou and reindeer & 662 & 0.083580582 & 680 & 0.085853166 \\
\hline Artiodactyla & Bovidae & Rupicapra & rupicapra & Chamois & 674 & 0.104919054 & 669 & 0.104140722 \\
\hline Carnivora & Felidae & Acinonyx & jubatus & Cheetah & 456 & 0.060942198 & 456 & 0.060942198 \\
\hline Rodentia & Chinchillidae & Chinchilla & lanigera & Chinchilla & 240 & 0.038228735 & 240 & 0.038228735 \\
\hline Artiodactyla & Tayassuidae & Pecari & tajacu & Collared peccary & 329 & 0.028614916 & 358 & 0.031137204 \\
\hline Chiroptera & Vespertilionidae & Pipistrellus & pipistrellus & Common pipistrelle & 456 & 0.078082192 & 456 & 0.078082192 \\
\hline Artiodactyla & Bovidae & Ovis & dalli & Dall's sheep & 684 & 0.095610847 & 639 & 0.08932066 \\
\hline Carnivora & Felidae & Felis & catus & Domestic cat & 289 & 0.026392694 & & \\
\hline Rodentia & Sciuridae & Tamias & striatus & Eastern chipmunk & 187 & 0.053929344 & 228 & 0.065753425 \\
\hline Rodentia & Sciuridae & Sciurus & carolinensis & Eastern gray squirrel & 343 & 0.039818899 & 401 & 0.046552124 \\
\hline Chiroptera & Vespertilionidae & Pipistrellus & subflavus & Eastern pipistrelle & 212 & 0.039244724 & & \\
\hline Lagomorpha & Leporidae & Lepus & europaeus & European hare & 236 & 0.060427602 & & \\
\hline Carnivora & Mustelidae & Mustela & putorius & European polecat & 312 & 0.077008515 & 322 & 0.079476737 \\
\hline Carnivora & Mustelidae & Martes & pennanti & Fisher & 365 & 0.06993007 & 365 & 0.06993007 \\
\hline Primates & Cercopithecidae & Theropithecus & gelada & Gelada baboon & 1391 & 0.10585997 & 2190 & 0.166666667 \\
\hline Carnivora & Ursidae & Ailuropoda & melanoleuca & Giant panda & 2192 & 0.163192376 & 2192 & 0.163192376 \\
\hline Rodentia & Muridae & Mesocricetus & auratus & Golden hamster & 48 & 0.033719705 & 48 & 0.033719705 \\
\hline Primates & Callitrichidae & Leontopithecus & rosalia & Golden lion tamarin & 547 & 0.047425004 & 730 & 0.063291139 \\
\hline Rodentia & Sciuridae & Spermophilus & lateralis & Golden-mantled ground squirrel & 637 & 0.167808219 & & \\
\hline Carnivora & Canidae & Urocyon & cinereoargenteus & Gray fox & 345 & 0.058346017 & 365 & 0.061728395 \\
\hline Primates & Cheirogaleidae & Microcebus & murinus & Gray mouse lemur & 243 & 0.036579858 & 243 & 0.036579858 \\
\hline Carnivora & Phocidae & Halichoerus & grypus & Gray seal & 1460 & 0.093240093 & 1887 & 0.120509627 \\
\hline Chiroptera & Rhinolophidae & Rhinolophus & ferrumequinum & Greater horseshoe bat & 730 & 0.06557377 & 730 & 0.06557377 \\
\hline Primates & Cercopithecidae & Papio & hamadryas & Hamadryas baboon & 1514 & 0.110611872 & 1762 & 0.128730594 \\
\hline Carnivora & Phocidae & Phoca & vitulina & Harbor seal & 1095 & 0.06302521 & 1460 & 0.084033613 \\
\hline Artiodactyla & Bovidae & Hemitragus & jemlahicus & Himalayan tahr & 547 & 0.068744502 & 730 & 0.091743119 \\
\hline Perissodactyla & Equidae & Equus & caballus & Horse & 914 & 0.043931747 & 973 & 0.046767604 \\
\hline Primates & Hominidae & Homo & sapiens & Human & 4745 & 0.106122449 & 5110 & 0.114285714 \\
\hline Artiodactyla & Bovidae & Aepyceros & melampus & Impala & 456 & 0.04880137 & 395 & 0.042273116 \\
\hline Primates & Cercopithecidae & Macaca & fuscata & Japanese macaque & 1483 & 0.105532823 & 1369 & 0.097420388 \\
\hline Cetacea & Delphinidae & Orcinus & orca & Killer whale & 3780 & 0.115068493 & 4930 & 0.150076104 \\
\hline Artiodactyla & Bovidae & Kobus & kob & Kob & 403 & 0.050415963 & 365 & 0.0456621 \\
\hline Carnivora & Felidae & Panthera & leo & Lion & 1095 & 0.111111111 & 1095 & 0.111111111 \\
\hline Chiroptera & Vespertilionidae & Myotis & lucifugus & Little brown bat & 210 & 0.016921837 & 210 & 0.016921837 \\
\hline Primates & Cercopithecidae & Macaca & fascicularis & Long-tailed macaque & 1238 & 0.086968739 & 1544 & 0.108465051 \\
\hline Rodentia & Dipodidae & Zapus & hudsonius & Meadow jumping mouse & 61 & 0.029843444 & 61 & 0.029843444 \\
\hline Artiodactyla & Bovidae & Procapra & gutturosa & Mongolian gazelle & 532 & 0.121461187 & & \\
\hline Artiodactyla & Bovidae & Ovis & aries & Mouflon & 548 & 0.065849555 & 914 & 0.109829368 \\
\hline Chiroptera & Vespertilionidae & Myotis & myotis & Mouse-eared bat & 502 & 0.062515567 & 502 & 0.062515567 \\
\hline Artiodactyla & Cervidae & Odocoileus & hemionus & Mule deer & 478 & 0.059526775 & 503 & 0.0626401 \\
\hline Rodentia & Muridae & Onychomys & leucogaster & Northern grasshopper mouse & 100 & 0.048923679 & 114 & 0.055772994 \\
\hline Rodentia & Echimyidae & Myocastor & coypus & Nutria & 152 & 0.048992748 & 152 & 0.048992748 \\
\hline Carnivora & Mustelidae & Meles & meles & Old World badger & 365 & 0.053763441 & 365 & 0.053763441 \\
\hline Lagomorpha & Leporidae & Oryctolagus & cuniculus & Old World rabbit & 730 & 0.222222222 & & \\
\hline Cetacea & Delphinidae & Stenella & attenuata & Pantropical spotted dolphin & 2983 & 0.177665277 & 3956 & 0.235616438 \\
\hline Primates & Cercopithecidae & Macaca & nemestrina & Pigtail macaque & 1125 & 0.081973186 & 1095 & 0.079787234 \\
\hline Passeriformes & Corvidae & Gymnorhinus & cyanocephalus & Pinyon jay & 365 & 0.090909091 & 365 & 0.090909091 \\
\hline Carnivora & Ursidae & Ursus & maritimus & Polar bear & 1734 & 0.108463126 & 1734 & 0.108463126 \\
\hline Carnivora & Canidae & Nyctereutes & procyonoides & Raccoon dog & 304 & 0.050173296 & 304 & 0.050173296 \\
\hline Artiodactyla & Cervidae & Cervus & elaphus & Red deer & 852 & 0.074103066 & 730 & 0.063492063 \\
\hline Carnivora & Canidae & Vulpes & vulpes & Red fox & 304 & 0.039102193 & 304 & 0.039102193 \\
\hline Rodentia & Sciuridae & Tamiasciurus & hudsonicus & Red squirrel & 342 & 0.095610847 & & \\
\hline Primates & Cercopithecidae & Macaca & mulatta & Rhesus monkey & 1231 & 0.084315068 & 2007 & 0.137465753 \\
\hline Carnivora & Mustelidae & Martes & zibellina & Sable & 456 & 0.067897558 & 456 & 0.067897558 \\
\hline Primates & Callitrichidae & Saguinus & fuscicollis & Saddlebacked tamarin & 546 & 0.06007592 & 730 & 0.080321285 \\
\hline Chiroptera & Phyllostomidae & Carollia & perspicillata & Seba's short-tailed bat & 258 & 0.041579371 & 258 & 0.041579371 \\
\hline Cetacea & Delphinidae & Globicephala & macrorhynchus & Short-finned pilot whale & 3470 & 0.15090237 & 5332 & 0.231876495 \\
\hline Carnivora & Otariidae & Arctocephalus & australis & South American fur seal & 1095 & 0.098039216 & 2556 & 0.228847703 \\
\hline Primates & Cebidae & Saimiri & sciureus & South American squirrel monkey & 1003 & 0.090991563 & 1826 & 0.165653633 \\
\hline Carnivora & Mephitidae & Mephitis & mephitis & Striped skunk & 335 & 0.066029368 & 335 & 0.066029368 \\
\hline Artiodactyla & Bovidae & Damaliscus & lunatus & Topi & 639 & 0.074181565 & & \\
\hline Primates & Cercopithecidae & Macaca & sinica & Toque macaque & 1460 & 0.136518771 & & \\
\hline Artiodactyla & Bovidae & Kobus & ellipsiprymnus & Waterbuck & 771 & 0.070410959 & & \\
\hline Artiodactyla & Cervidae & Capreolus & capreolus & Western roe deer & 413 & 0.064657534 & 655 & 0.102544031 \\
\hline Perissodactyla & Rhinocerotidae & Ceratotherium & simum & White rhinoceros & 1643 & 0.100030441 & 1643 & 0.100030441 \\
\hline Artiodactyla & Tayassuidae & Tayassu & pecari & White-lipped peccary & 548 & 0.052679644 & 548 & 0.052679644 \\
\hline Artiodactyla & Cervidae & Odocoileus & virginianus & White-tailed deer & 309 & 0.039193303 & 417 & 0.052891933 \\
\hline Primates & Callitrichidae & Callithrix & jacchus & White-tufted-ear marmoset & 477 & 0.079202989 & 382 & 0.063428809 \\
\hline Artiodactyla & Suidae & Sus & scrofa & Wild Boar & 334 & 0.033891426 & 768 & 0.077929985 \\
\hline Rodentia & Sciuridae & Marmota & flaviventris & Yellow-bellied marmot & 730 & 0.094339623 & 730 & 0.094339623 \\
\hline
\end{tabular}


bioRxiv preprint doi: https://doi.org/10.1101/048835; this version posted April 15, 2016. The copyright holder for this preprint (which was not certified by peer review) is the author/funder. All rights reserved. No reuse allowed without permission.

\begin{tabular}{|c|c|c|c|c|c|c|c|c|c|c|}
\hline $\begin{array}{l}\text { Number of } \\
\text { Days in } \\
\text { Gestation }\end{array}$ & $\begin{array}{l}\text { Number of } \\
\text { Days to } \\
\text { Weaning }\end{array}$ & $\begin{array}{l}\text { Average } \\
\text { Litter Size }\end{array}$ & $\begin{array}{l}\text { Number of } \\
\text { Litters per } \\
\text { Year }\end{array}$ & $\begin{array}{l}\text { Weight at } \\
\text { Birth (g) }\end{array}$ & $\begin{array}{l}\text { Weight at } \\
\text { Weaning }(g)\end{array}$ & $\begin{array}{l}\text { Weaning } \\
\text { Weight/Adult } \\
\text { Weight }\end{array}$ & $\begin{array}{l}\text { Adult Weight } \\
\text { (g) }\end{array}$ & Offspring Ratio & $\begin{array}{l}\text { Litter-Adjusted } \\
\text { Offspring Ratio }\end{array}$ & $\begin{array}{l}\text { Growth } \\
\text { (per day }\end{array}$ \\
\hline 331 & 289 & 1 & 0.4 & 44000 & 166000 & 0.237142857 & 700000 & 0.062857 & 0.062857 & 0.0026 \\
\hline 359 & & 1 & & 30000 & & & 164998 & 0.18182 & 0.18182 & \\
\hline 128 & 60 & 3.5 & 1 & 430 & & & 20250 & 0.021235 & 0.0743225 & \\
\hline 70 & 198 & 2 & 0.4 & 277.5 & 14050 & 0.0910859 & 154250 & 0.001799 & 0.003598 & 0.0029 \\
\hline 273 & 68 & 1.02 & 1 & 3000 & 66900 & 0.743333333 & 90000 & 0.033333 & 0.03399966 & \\
\hline 60 & & 2.5 & 2 & 39 & & & 1331.5 & 0.02929 & 0.073225 & \\
\hline 35 & & 2 & & 3.9 & 17.2 & 0.747826087 & 23 & 0.169565 & 0.33913 & 0.062 \\
\hline 180 & 152 & 1 & 1 & 4400 & 28000 & 0.398434721 & 70275 & 0.062611 & 0.062611 & 0.0031 \\
\hline 30 & 63 & 4 & 1 & 15.75 & 148.35 & 0.131866667 & 1125 & 0.014 & 0.056 & 0.0111 \\
\hline 253 & 278 & 1 & 1 & 18125 & & & 164500 & 0.110182 & 0.110182 & 0.0026 \\
\hline 65 & 65 & 3 & 0.9 & 265 & 1190 & 0.138372093 & 8600 & 0.030814 & 0.092442 & 0.0068 \\
\hline 161 & 304 & 1 & 1 & 394 & 2000 & 0.29607698 & 6755 & 0.058327 & 0.058327 & \\
\hline 30 & 106 & 7 & & 0.016 & 16 & 0.581818182 & 27.5 & 0.000582 & 0.004074 & \\
\hline 103 & 213 & 2 & 0.4 & 510 & 26000 & 0.093693694 & 277500 & 0.001838 & 0.003676 & \\
\hline 365 & 395 & 1 & 0.6 & 32000 & 205000 & 0.732142857 & 280000 & 0.114286 & 0.114286 & 0.0038 \\
\hline 335 & 456 & 1 & 0.4 & 32000 & & & 322000 & 0.099379 & 0.099379 & 0.0024 \\
\hline 228 & 120 & 1 & 1 & 6500 & 20000 & 0.197530864 & 101250 & 0.064198 & 0.064198 & 0.0047 \\
\hline 122 & 76 & 1 & 1 & 2400 & & & 37500 & 0.064 & 0.064 & \\
\hline 88 & 107 & 3 & 0.7 & 489 & 1940 & 0.036261682 & 53500 & 0.00914 & 0.02742 & \\
\hline 111 & 54 & 2 & 2 & 35 & & & 642.5 & 0.054475 & 0.10895 & \\
\hline 145 & 49 & 2 & 2 & 700 & 4881 & 0.241633663 & 20200 & 0.034653 & 0.069306 & \\
\hline 42 & 42 & 1.2 & & 1.125 & & & 5 & 0.225 & 0.27 & 0.0668 \\
\hline 173 & 129 & 1 & 1 & 2819 & & & 73100 & 0.038564 & 0.038564 & \\
\hline 65 & 56 & 4 & & 97.5 & & & 3900 & 0.025 & 0.1 & \\
\hline 31 & 36 & 5 & 1.5 & 3.4 & 50.5 & 0.526041667 & 96 & 0.035417 & 0.177085 & \\
\hline 44 & 66 & 4 & 2 & 15 & 200 & 0.375234522 & 533 & 0.028143 & 0.112572 & 0.0234 \\
\hline 44 & & 2 & & 0.94 & 5.2 & 0.693333333 & 7.5 & 0.125333 & 0.250666 & \\
\hline 42 & 29 & 2 & 3.8 & 119.67 & 390 & 0.093413174 & 4175 & 0.028663 & 0.057326 & 0.0191 \\
\hline 42 & 63 & 7.5 & 1.5 & 9.5 & & & 809 & 0.011743 & 0.0880725 & 0.0328 \\
\hline 45 & 66 & 2.5 & 1 & 35 & & & 3175 & 0.011024 & 0.02756 & \\
\hline 168 & 433 & 1 & 0.5 & 464 & 3900 & 0.240740741 & 16200 & 0.028642 & 0.028642 & \\
\hline 48 & 182 & 1.5 & 0.7 & 110 & 22000 & 0.187234043 & 117500 & 0.000936 & 0.001404 & 0.0028 \\
\hline 16 & 20 & 9 & 3 & 2.45 & 22.93 & 0.218380952 & 105 & 0.023333 & 0.209997 & 0.0574 \\
\hline 128 & 131 & 2 & 1.8 & 55.3 & 165 & 0.25210084 & 654.5 & 0.084492 & 0.168984 & 0.0077 \\
\hline 30 & 37 & 5.12 & 0.94 & 6.26 & 74.2 & 0.470812183 & 157.6 & 0.039721 & 0.20337152 & 0.0411 \\
\hline 57 & 55 & 4 & 1 & 95 & 519.7 & 0.109410526 & 4750 & 0.02 & 0.08 & 0.0127 \\
\hline 61 & 37 & 2 & 1 & 6 & & & 64.8 & 0.092593 & 0.185186 & 0.0362 \\
\hline 240 & 19 & 1 & 0.9 & 14000 & 41450 & 0.154664179 & 268000 & 0.052239 & 0.052239 & \\
\hline 80 & 60 & 1 & & 5.8 & & & 22.875 & 0.253552 & 0.253552 & \\
\hline 171 & 300 & 1 & 0.8 & 814 & 3950 & 0.219444444 & 18000 & 0.045222 & 0.045222 & 0.0026 \\
\hline 253 & 30 & 1 & 1 & 11000 & 23945 & 0.208217391 & 115000 & 0.095652 & 0.095652 & 0.0013 \\
\hline 183 & 151 & 1 & 1 & 2000 & & & 35200 & 0.056818 & 0.056818 & \\
\hline 337 & 274 & 1 & & 79200 & & & 250000 & 0.3168 & 0.3168 & \\
\hline 280 & 639 & 1 & 0.3 & 3312.5 & 11750 & 0.189409204 & 62035 & 0.053397 & 0.053397 & 0.0005 \\
\hline 198 & 167 & 1 & 1 & 5550 & 15900 & 0.302857143 & 52500 & 0.105714 & 0.105714 & 0.0043 \\
\hline 174 & 366 & 1.5 & 0.5 & 496 & 1767 & 0.198930481 & 8882.5 & 0.05584 & 0.08376 & \\
\hline 435 & 471 & 1 & 0.2 & 180000 & & & 3990000 & 0.045113 & 0.045113 & \\
\hline 251 & 189 & 1 & 1.3 & 5405 & 31600 & 0.300952381 & 105000 & 0.051476 & 0.051476 & \\
\hline 109 & 216 & 3 & 1 & 1300 & 8480 & 0.048457143 & 175000 & 0.007429 & 0.022287 & 0.0035 \\
\hline 55 & 25 & 1 & & 1.96 & & & 10 & 0.196 & 0.196 & 0.116 \\
\hline 165 & 242 & 1 & 0.9 & 320 & 848.4 & 0.133343811 & 6362.5 & 0.050295 & 0.050295 & \\
\hline 19 & 28 & 5.5 & 2.1 & 0.8 & 7.8 & 0.433333333 & 18 & 0.044444 & 0.244442 & 0.0328 \\
\hline 185 & & 1.3 & 1 & 2900 & & & 30000 & 0.096667 & 0.1256671 & \\
\hline 146 & 182 & 1.58 & 1 & 2370 & 17500 & 0.159090909 & 110000 & 0.021545 & 0.0340411 & \\
\hline 65 & 42 & 1 & & 5.9 & & & 28.55 & 0.206655 & 0.206655 & 0.109 \\
\hline 207 & 132 & 1.5 & 1 & 2950 & 23100 & 0.405263158 & 57000 & 0.051754 & 0.077631 & 0.0057 \\
\hline 31 & 23 & 4 & 2.5 & 2.6 & 13.1 & 0.403076923 & 32.5 & 0.08 & 0.32 & 0.0634 \\
\hline 131 & 91 & 6 & 2.3 & 225 & 1750 & 0.222929936 & 7850 & 0.028662 & 0.171972 & \\
\hline 49 & 90 & 3 & 1 & 80 & & & 13000 & 0.006154 & 0.018462 & 0.0196 \\
\hline 30 & 26 & 5 & 4.3 & 45 & 214 & 0.118888889 & 1800 & 0.025 & 0.125 & 0.0228 \\
\hline 345 & 543 & 1 & 0.3 & 10000 & & & 112500 & 0.088889 & 0.088889 & \\
\hline 172 & 324 & 1 & 0.8 & 462.5 & 1416.5 & 0.179020537 & 7912.5 & 0.058452 & 0.058452 & 0.0015 \\
\hline 17 & & 4 & 1 & 6.26 & & & 105 & 0.059619 & 0.238476 & 0.303 \\
\hline 230 & 303 & 2 & 0.4 & 665 & 27000 & 0.056842105 & 475000 & 0.0014 & 0.0028 & 0.0022 \\
\hline 61 & 47 & 6 & 1 & 75 & 825 & 0.126923077 & 6500 & 0.011538 & 0.069228 & \\
\hline 245 & 156 & 1 & 0.9 & 10100 & 56500 & 0.2825 & 200000 & 0.0505 & 0.0505 & 0.006 \\
\hline 52 & 48 & 5 & 1 & 100 & 1397 & 0.338117482 & 4131.7 & 0.024203 & 0.121015 & 0.0177 \\
\hline 37 & 63 & 4.2 & 1.7 & 7 & 83.8 & 0.419 & 200 & 0.035 & 0.147 & 0.0216 \\
\hline 165 & 292 & 1 & 1 & 464 & 1454 & 0.176563449 & 8235 & 0.056345 & 0.056345 & 0.0012 \\
\hline 30 & 56 & 3 & & 30 & 600 & 0.562482422 & 1066.7 & 0.028124 & 0.084372 & \\
\hline 147 & 91 & 1.8 & 1 & 39.9 & & & 456.5 & 0.087404 & 0.1573272 & \\
\hline 95 & & 1 & & 5 & 12.5 & 0.833333333 & 15 & 0.333333 & 0.333333 & 0.0347 \\
\hline 452 & 730 & 1 & 0.2 & 60000 & & & 2200000 & 0.027273 & 0.027273 & \\
\hline 236 & 411 & 1 & 1 & 4250 & & & 110000 & 0.038636 & 0.038636 & \\
\hline 161 & 177 & 1 & 1 & 107 & 403 & 0.435675676 & 925 & 0.115676 & 0.115676 & 0.0125 \\
\hline 63 & 60 & 5 & 1 & 33.5 & 493.5 & 0.141 & 3500 & 0.009571 & 0.047855 & 0.0143 \\
\hline 238 & & 1 & 0.6 & 11100 & & & 110000 & 0.100909 & 0.100909 & \\
\hline 152 & 396 & 1 & 0.7 & 446 & & & 4370 & 0.102059 & 0.102059 & \\
\hline 264 & 213 & 1 & 1 & 9000 & & & 175333 & 0.051331 & 0.051331 & \\
\hline 153 & 89 & 1.6 & 1 & 1010 & 8692.5 & 0.40119169 & 21666.7 & 0.046615 & 0.074584 & \\
\hline 515 & 365 & 1 & 0.4 & 52500 & & & 2180000 & 0.024083 & 0.024083 & \\
\hline 158 & 50 & 2 & & 700 & & & 22000 & 0.031818 & 0.063636 & \\
\hline 198 & 129 & 2 & 1 & 3000 & 36000 & 0.413793103 & 87000 & 0.034483 & 0.068966 & 0.007 \\
\hline 144 & 62 & 2 & 2 & 26.5 & 86.67 & 0.339615987 & 255.2 & 0.10384 & 0.20768 & 0.0172 \\
\hline 115 & 56 & 7 & 1.5 & 960 & 5700 & 0.031666667 & 180000 & 0.005333 & 0.037331 & 0.0095 \\
\hline 30 & 33 & 4 & 0.9 & 33.8 & 479 & 0.136857143 & 3500 & 0.009657 & 0.038628 & \\
\hline
\end{tabular}


bioRxiv preprint doi: https://doi.org/10.1101/048835; this version posted April 15, 2016. The copyright holder for this preprint (which was not certified by peer review) is the author/funder. All rights reserved. No reuse allowed without permission.

Maximum Maximum Age of

Age Reproductive

PRLS

(Days)

$\begin{array}{llll}29.8 & 10877 & 6570 & 0.301212508 \\ 47 & 17155 & 7300 & 0.556150058\end{array}$

$\begin{array}{llll}17155 & 7300 & 0.536150058 \\ 23.4 & 8541 & 5475 & 0.307137434\end{array}$

$34 \quad 12410 \quad 8151.545 \quad 0.267737603$

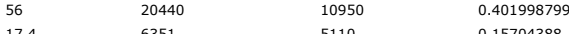

$\begin{array}{llll}17.4 & 5110 & 0.401998799 \\ 19 & 6935 & 5475 & 0.142943824233\end{array}$

$\begin{array}{llll}20.6 & 7519 & 6205 & 0.089107457\end{array}$

$\begin{array}{llll}11 & 4015 & 2190 & 0.333333333 \\ 24.3 & 8869.5 & 6570 & 0.223266537\end{array}$

$\begin{array}{llll}32.3 & 11789.5 & 4380 & 0.616613419 \\ 3.4 & 10950 & 8503 & 0.119316416\end{array}$

$\begin{array}{lll}10950 & 8503 & 0.119316416 \\ 1971 & 315 & 0.81316726\end{array}$

$\begin{array}{lll}1971 & 315 & 0.81316726\end{array}$

$\begin{array}{lll}14600 & 7300 & 0.450590803 \\ 13870 & 6935 & 0.46530454\end{array}$

$\begin{array}{lll}13870 & 6935 & 0.465304549 \\ 20440 & 6980 & 0.00997965\end{array}$

$\begin{array}{lll}20440 & 18980 & 0.009497965\end{array}$

$\begin{array}{lll}7920.5 & 4745 & 0.346283667\end{array}$

$\begin{array}{lll}6424 & 3650 & 0.365217391 \\ 7482.5 & 4745 & 0.324699352\end{array}$

$\begin{array}{lll}6278 & 5475 & 0.324699352 \\ 14975 & 0.093242796\end{array}$

$11497.5 \quad 3650$

$\begin{array}{lll}5840 & 2555 & 0.525445765\end{array}$

$\begin{array}{lll}7154 & 4562.5 & 0.294822257\end{array}$

$\begin{array}{lll}7154 & 5110 & 0.520682863 \\ 3467.5 & 2555 & 0.221155312\end{array}$

$\begin{array}{lll}3467.5 & 2555 & 0.221155312 \\ 8614 & 2555 & 0.69108348\end{array}$

0.691089348

$3402-0.365052025$

$\begin{array}{lll}5905.5 & 1825 & 0.502657038 \\ 4051.5 & 2555 & 0.316753577\end{array}$

$5219.5-3650-0.248120301$

$\begin{array}{lll}13140 & 6935 & 0.409736999\end{array}$

$\begin{array}{lll}13432 & 3285 & 0.70774021\end{array}$

$\begin{array}{lll}1423.5 & 180 & 0.869138495 \\ 11534 & 10122 & 0.078729407 \\ 3796 & 2098.75 & 0.35628363\end{array}$

$\begin{array}{lll}11534 & 10122 & 0.078729407 \\ 3796 & 2098.75 & 0.335628363\end{array}$

$\begin{array}{lll}5913 & 2920 & 0.335628363 \\ 613 & & 0.475574713\end{array}$

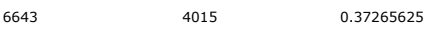

$11315-0.20308483$

$9125-0.122807018$

$\begin{array}{lll}13687.5 & 9490 & 0.220437836\end{array}$

7957

20805

44712.5
9344

9344
14052.5

32850
7993.5

7993.5
9855

9855

12410

14235

2044

4380
8322
8030
8030

8030

2044
3102.5

6789

3285

16790
13724

13724
4015

15987

6059
11497.5

7774.5

3577

14600

6716
9088.5

6205

22995

11169

11023

8614
10694.5

10950

6387.5

16425
10402.5
7884

7884

6022.5

9855
7738

0.408906883

0.229299683

0.543378995

0.548267327

0.274036358

0.397316821

0.663395033

0.663395033

0.416666667

0.606832346

0.44806354

0.33601871

0.74176743

0.272715197

0.323358051
0.385288066

0.385288066
0.381460769

0.381460769
0.318181818

0.285714286

0.074744695

0.027272006

0.48

0.411001193

0.55603822

0.39998121

0.674274369

0.548686244

0.317450819

0.18370607

0.108047995

0.386245166

0.252240717

0.27536231

0.01952095

0.537828427

0.72539185

0.40714625

0.605560468
0.450163194

0.11108104

0.85184433

0.66270627

0.05310612

0.731645836
0.479166667

Increase in Mortality Rate Basal Metabolic Body

Doubling Time Basal Metabolic Temperature

(per year)

(Years)

(K)

164.92

0.113

2.358

$230.073 \quad 311.15$

$0.189 \quad 308.25$

70.0056

119.66

61.77

1.31

312.15

0.36

33.165

310.65

0.05

4
1.5

$\begin{array}{ll}0.813 & 311.35 \\ 2.062 & 311.85\end{array}$

0.69

311.25

0.967

309.45

0.06

21.095

0.0002

0.0002

82.78

310.15

$94.58 \quad 311.05$

0.051

0.219

$\begin{array}{ll}16.647 & 310.15 \\ 7.395 & 312.15\end{array}$

0.02

112.43

$\begin{array}{ll}13.731 & 311.85 \\ 1.615 & 311.85\end{array}$

15

$0.24 \quad 309.55$

0.017

4.429

311.15

148.949

311.15

$123.447-312.15$
0.848

0.848

104.15

309.15

09.65 
bioRxiv preprint doi: https://doi.org/10.1101/048835; this version posted April 15, 2016. The copyright holder for this preprint (which was not certified by peer review) is the author/funder. All rights reserved. No reuse allowed without permission.

Datatable 2

\begin{tabular}{|c|c|c|c|c|c|c|c|c|c|c|}
\hline Name & $\begin{array}{l}\text { Age of } \\
\text { Reproductive } \\
\text { Senescence }\end{array}$ & $\begin{array}{l}\text { Age of } \\
\text { Maturity }\end{array}$ & $\begin{array}{l}\text { Maturity } \\
\text { Proportion } \\
\text { (yrs) }\end{array}$ & Max Age & PRLS & $\begin{array}{l}\text { Birth Weight } \\
\text { or Size }\end{array}$ & $\begin{array}{l}\text { Adult } \\
\text { Weight or } \\
\text { Size }\end{array}$ & $\begin{array}{l}\text { Offspring } \\
\text { Ratio }\end{array}$ & Litter Size & $\begin{array}{l}\text { Litter- } \\
\text { Adjusted } \\
\text { Offspring } \\
\text { Ratio }\end{array}$ \\
\hline Strongylocentrotus franciscanus & 5 max - 1day* & $1.5 \mathrm{yrs}$ & 0.0075 & $200 y r s$ & $1.38 \mathrm{E}-05$ & $0.01 \mathrm{~cm}$ & $61 \mathrm{~cm}$ & $4.41 \mathrm{E}-12$ & 1000000 & $4.41 \mathrm{E}-06$ \\
\hline Strongylocentroltus purpuratus & $\max -1$ day* & $2 y r s$ & 0.04 & $50 y r s$ & $5.71 \mathrm{E}-05$ & $0.01 \mathrm{~cm}$ & $5 \mathrm{~cm}$ & $8.00 \mathrm{E}-09$ & 1000000 & $8.00 \mathrm{E}-03$ \\
\hline Oncorhynchus tshawytscha & max - 1day* & $4.65 y \mathrm{ys}$ & 0.58125 & $8 y r s$ & $8.18 \mathrm{E}-04$ & $361 \mathrm{~g}$ & $18 \mathrm{~kg}$ & $2.01 \mathrm{E}-05$ & 5021 & $1.01 \mathrm{E}-01$ \\
\hline Oncorhynchus keta & $\max$ - 1day* & $3 y r s$ & 0.428571 & 7yrs & 0.000694 & $276 \mathrm{~g}$ & $5.2 \mathrm{~kg}$ & $5.32 \mathrm{E}-05$ & 2967 & $1.58 \mathrm{E}-01$ \\
\hline Oncorhynchus kisutch & $\max$ - 1day* & $2.75 \mathrm{yrs}$ & 0.458333 & 6yrs & 8.43E-04 & $193 \mathrm{~g}$ & $3.6 \mathrm{~kg}$ & $5.35 \mathrm{E}-05$ & 2915 & $1.56 \mathrm{E}-01$ \\
\hline Gallus gallus domesticus & $2.5 \mathrm{yrs}$ & $19 w k s$ & 0.091346 & $4 \mathrm{yrs}$ & 0.312169 & $53.3 \mathrm{~g}$ & $4077 \mathrm{~g}$ & 0.013073 & 250 & $3.27 E+00$ \\
\hline Passeriformes & $5.2 \mathrm{yrs}$ & $1 \mathrm{yr}$ & 0.090909 & $11 \mathrm{yrs}$ & 0.527 & $6.26 \mathrm{~g}$ & $105 \mathrm{~g}$ & 0.059619 & 4 & $2.38 \mathrm{E}-01$ \\
\hline Mabuya buettneri & 1month & 2 month & 0.166667 & $1 \mathrm{yr}$ & 0.1 & $0.367 \mathrm{~g}$ & $16.2 \mathrm{~g}$ & 0.022637 & 9 & 2.04E-01 \\
\hline Drosophila Melanogaster & 50.5 days & 7.5 days & 0.141509 & 53days & 0.054945 & 9.7 microgram & $0.9 \mathrm{mg}$ & 0.010778 & 1137 & $1.23 \mathrm{E}+01$ \\
\hline Mammals & $15.8 \mathrm{yrs}$ & $2.30 \mathrm{yrs}$ & 0.083333 & $27.6 y r s$ & 0.375494 & $\quad 7634 \mathrm{~g}$ & $161865 \mathrm{~g}$ & 0.071765 & 3 & $2.15 \mathrm{E}-01$ \\
\hline Galeorhinus galeus & $41 \mathrm{yrs}$ & $12.5 \mathrm{yrs}$ & 0.227273 & $55 y r s$ & 0.329412 & $35 \mathrm{~cm}$ & $134 \mathrm{~cm}$ & 0.017819 & 29 & 0.516759 \\
\hline Alligator mississippiensis & $45 y r s$ & $12 \mathrm{yrs}$ & 0.2 & $60 y r s$ & 0.3125 & $71.2 \mathrm{~mm}$ & $2600 \mathrm{~mm}$ & $2.05 \mathrm{E}-05$ & 42.5 & 0.000873 \\
\hline
\end{tabular}

